\title{
Life cycle costs of advanced treatment techniques for wastewater reuse and resource recovery from sewage sludge
}

DOI:

10.1016/j.jclepro.2018.08.300

\section{Document Version}

Accepted author manuscript

Link to publication record in Manchester Research Explorer

Citation for published version (APA):

Zepon Tarpani, R. R., \& Azapagic, A. (2018). Life cycle costs of advanced treatment techniques for wastewater reuse and resource recovery from sewage sludge. Journal of Cleaner Production, 204, 832-847.

https://doi.org/10.1016/j.jclepro.2018.08.300

\section{Published in:}

Journal of Cleaner Production

\section{Citing this paper}

Please note that where the full-text provided on Manchester Research Explorer is the Author Accepted Manuscript or Proof version this may differ from the final Published version. If citing, it is advised that you check and use the publisher's definitive version.

\section{General rights}

Copyright and moral rights for the publications made accessible in the Research Explorer are retained by the authors and/or other copyright owners and it is a condition of accessing publications that users recognise and abide by the legal requirements associated with these rights.

\section{Takedown policy}

If you believe that this document breaches copyright please refer to the University of Manchester's Takedown Procedures [http://man.ac.uk/04Y6Bo] or contact uml.scholarlycommunications@manchester.ac.uk providing relevant details, so we can investigate your claim.

\section{OPEN ACCESS}




\title{
Life cycle costs of advanced treatment techniques for wastewater reuse and resource recovery from sewage sludge
}

\author{
Raphael Ricardo Zepon Tarpani and Adisa Azapagic*
}

Sustainable Industrial Systems, School of Chemical Engineering and Analytical Science, Room C16, The Mill, Sackville Street, The University of Manchester, Manchester M13 9PL, UK. Phone: +44 (0) 1613064380

*Corresponding author: adisa.azapagic@manchester.ac.uk

\begin{abstract}
Water treated in advanced wastewater treatment plants (WWTP) could be reused as potable water to address water shortages. Furthermore, sludge from WWTPs can be used to recover nutrients, energy and chemicals. Thus, the role of WWTPs could change from traditional pollution control facilities to sources of freshwater and other valuable resources. However, the economic viability of advanced wastewater and sludge treatment methods aimed at production of potable water and recovery of other resources is currently unknown. To address this gap and inform their future development, this paper considers life cycle costs of the following four wastewater treatment methods: granular activated carbon, nanofiltration, solar photo-Fenton and ozonation. For recovery of resources from sludge, the following options are examined: agricultural application of anaerobically-digested and composted sludge, incineration, pyrolysis and wet air oxidation. Ozonation has the lowest life cycle costs, averaging $£ 112$ per $1,000 \mathrm{~m}^{3}$ of water treated, followed by nanofiltration at $£ 134$. Solar photo-Fenton is the most expensive option with $£ 238 / 1,000 \mathrm{~m}^{3}$. These costs are significantly lower than water desalination and could be competitive in the future with conventional potable water production. For resource recovery from sludge, anaerobic digestion, pyrolysis and wet air oxidation can operate at a profit with the negative overall life cycle costs $(-£ 65,-£ 291$ and $-£ 26 / 1,000 \mathrm{~kg}$ dry matter, respectively) if all their recovered products are fully utilised. The next best option is composting with the total life cycle costs of $£ 35 / 1,000 \mathrm{~kg}$ dry matter. Incineration is the least preferred alternative with the cost of nearly $£ 54 / 1,000 \mathrm{~kg}$ dry matter. Advanced wastewater and sludge treatment would increase the costs of conventional wastewater treatment by 1.5-2.1 times.
\end{abstract}

Keywords: life cycle costing; resource recovery; sewage sludge treatment; wastewater treatment, wastewater reuse

\section{Introduction}

Readily-available fresh water sources are steadily declining in many regions worldwide, with projections that over 3.6 billion people will live in water-scarce areas by 2050 (OECD 2012). Although the agricultural sector is at present the largest water consumer ( $70 \%$ of global use), growing urbanisation has led to a significant increase in water demand, particularly in large conurbations (McDonald et al. 2014, United Nations 2018). Combined with poor water quality in many regions, this has led to wastewater reuse being considered as a feasible option for increasing freshwater availability (Garcia \& Pargament 2015, Voulvoulis 2018), particularly for irrigation, which is increasing rapidly in Europe, United States, Australia and China (Zhang \& Shen 2017). More recently, wastewater reuse to increase potable water supplies has also been proposed due to technological improvements (Binz et al. 2016, Harris-Lovett et al. 2015, Smith et al. 2018). Successful examples of this practice can already be found in several cities in the United States, Namibia and South Africa, and is considered as an option in many others (Lahnsteiner et al. 2018).

However, conventional WWTPs cannot achieve the quality standards required for potable water and advanced effluent treatment techniques must be used to remove pathogens, heavy metals and other contaminants, including pharmaceutical and personal care products (PPCPs). PPCPs are a diverse group of substances that include analgesics, antibiotics, hormones, stimulants and antiseptics, usually present in WWTPs influents at concentrations below $\mu \mathrm{g} / \mathrm{L}$ (Bailey et al. 2018, Khan 2013, 
Soller et al. 2017, Tran et al. 2018). PPCPs are of particular concern as their presence in WWTPs effluents is increasing fast. This is due to a growing consumption of PPCPs and the subsequent human excretion of their compounds which reach WWTPs via municipal wastewaters (Lyons 2014, Pereira et al. 2017). Many of these substances have low removal efficiencies in conventional WWTPs and are often found in the environment, posing ecotoxicological risks (Archer et al. 2017, Wang \& Wang 2016).

A further attraction of WWTPs is that they produce sludge which can be used to recover valuable resources, such as nutrients, energy, fuels and chemicals. This is particularly important as these resources are becoming constrained in many world regions, including phosphorus (Elser \& Bennett 2011) and energy (Umbach 2010). Decentralised approaches to sludge treatment are being developed and are expected to have high penetration in developing countries in the future (Larsen et al. 2016, Libralato et al. 2012, Simha \& Ganesapillai 2017). However, in most developed countries, centralised sludge treatment is expected to continue to play a major role for most of the sludge produced in these regions due the already existing infrastructure (Mo \& Zhang 2013, Van Der Hoek et al. 2016). Presently, most sludge from biological wastewater treatment in Europe is either landfilled, incinerated or reused in agriculture (comprising $90 \%$ of their final destination in 2005) (Kelessidis \& Stasinakis 2012). These methods are riddled with the issues, such as the presence of pathogens, heavy metals, PPCPs, dioxins and other hazardous substances in the sludge, land occupation by landfills and leachates, pollution from incineration and associated health and socialacceptance concerns (eawag 2014). To address some of these problems, advanced sludge treatment techniques aimed at resource recovery and reduction of contaminants have been developed. Although still limited in commercial applications, examples of these treatment options include a pyrolysis plant in Perth, Australia (Fonts et al. 2012) and wet air oxidation facilities in France, Belgium and Italy (Hii et al. 2014).

Studies on the economics of advanced wastewater and sludge treatment methods are scarce. Estimates of costs for advanced wastewater treatment have been reported for granular activated carbon (Jeswani et al. 2015), nanofiltration (Bruggen et al. 2001), solar photo-Fenton and ozonation (Miralles-Cuevas et al. 2016). For the sludge treatments, only estimates for the most common methods - anaerobic digestion, composting and incineration - can be found (Lundin et al. 2004, Murray et al. 2008, Hong et al. 2009, Xu et al. 2014), with the first study being located in Europe and the other three in China and Japan. While these studies provide useful data, they have all used different assumptions and estimation methodologies and are based in different regions, not allowing comparisons among the techniques. Costs of technologies, such as pyrolysis and wet air oxidation, are not available in the literature.

To address these issues and fill knowledge gaps, this paper presents the life cycle costs (LCC) of a number of large-scale centralized advanced wastewater and sludge treatment techniques, with the aim of identifying economically most sustainable options and informing their future development. The advanced wastewater treatment options considered here are: i. granular activated carbon (GAC); ii. nanofiltration (NF); iii. solar-photo Fenton (SPF); and iv. ozonation. They were selected because they are either well established (i and ii) or are considered most promising methods for wastewater reuse (iii and iv). They are also all capable of treating wastewater to levels similar to potable-water standards and are efficient in removing PPCP compounds (González et al. 2015, Lofrano 2012). For the sludge treatment, the following methods are included: i. agricultural application of anaerobic digested sludge; ii. agricultural application of composted sludge; iii. incineration; iv. pyrolysis; and v. wet air oxidation. These were chosen here because they enable recovery of various resources (nutrients, energy, fuels and/or chemicals), with i-iii being currently most widely practiced in Europe (Kelessidis \& Stasinakis 2012) and iv and v considered promising techniques that could play a greater role in the future (Fytili \& Zabaniotou 2008, Tyagi \& Lo 2013). 
As far as the authors are aware, this the first study to consider LCC of these methods, combining both wastewater and sludge treatment within the same estimation framework.

\section{Methods}

\subsection{Goal and scope of the study}

The goal of the study was to estimate the life cycle costs of the selected advanced wastewater treatment methods aimed at wastewater reuse and sludge handling techniques aimed at resource recovery. As illustrated in Figure 1, the scope was from cradle to grave, comprising plant construction and operation, periodic equipment replacement, waste management and recovery of resources. Decommissioning of treatment plants was not considered due to a lack of data and high uncertainty of these costs at the end of their useful lifetime. The sludge treatment systems were credited for the revenue from the sales of the recovered resources but not the advanced wastewater plants for the recovery of potable water for the reasons discussed in the next section. As the focus of the study is on centralised treatments, it was assumed that the advanced treatment plants are coupled with conventional WWTPs serving 150,000 inhabitants and treating $64,000 \mathrm{~m}^{3} /$ day of wastewater, which generates $7,500 \mathrm{~kg}$ /day of sludge (on a dry basis). This scale of the plant was selected for the following three key reasons. First, it was assumed that the secondary treatment was carried out in a membrane bioreactor (MBR) which is more effective in reducing total suspended solids, biochemical oxygen demand and organic compounds than the standard activated sludge process (Hai \& Yamamoto 2011, Laera et al. 2012) and hence enables a more efficient operation of the advanced treatments. Secondly, the plants were assumed to be located in the UK, where the average capacity of WWTPs corresponds to the chosen size of the plant (DEFRA 2012). Finally, this size is also suitable as some of the advanced treatment techniques are not yet available for treating larger amounts of effluent or sludge.

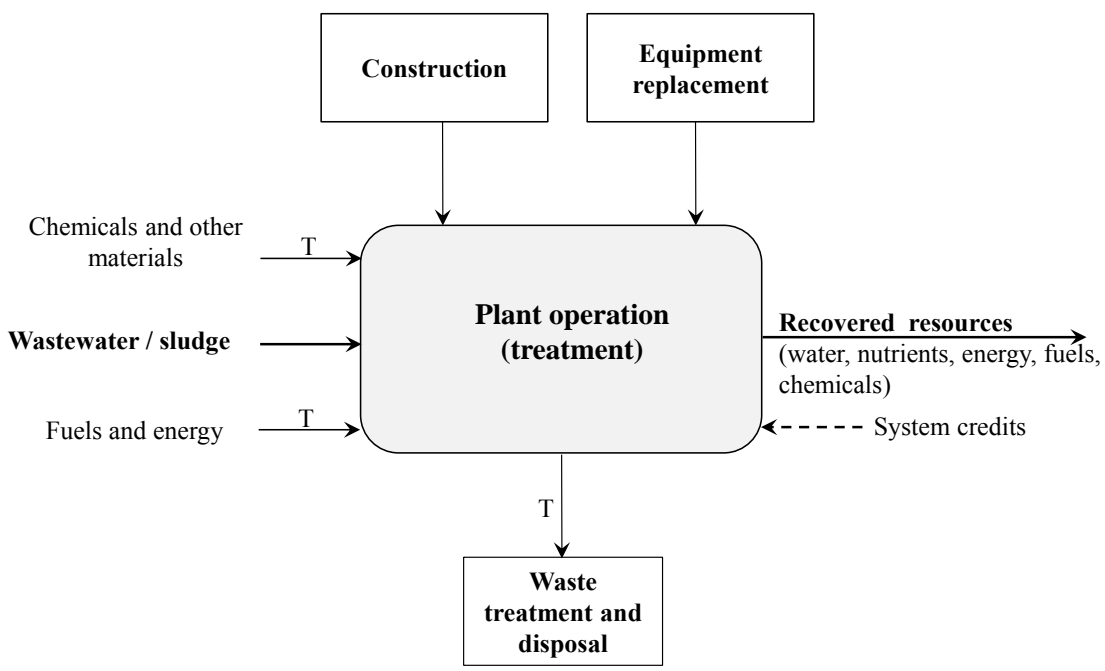

Figure 1 - System boundaries and life cycle stages considered in the study

(System credits apply only to sludge treatment. Plant decommissioning is excluded from the system boundary. T: transport. For transport details, see Table 3)

The functional unit for the advanced wastewater treatment was defined as the "treatment of 1,000 $\mathrm{m}^{3}$ of effluent from conventional wastewater treatment". For sludge, the functional unit was "treatment of $1,000 \mathrm{~kg}$ of thickened sludge on a dry basis". Based on Bonton et al. (2012), the lifetime of the advanced treatment plants was assumed to be 60 years, matching the lifetime of conventional WWTPs (Pasqualino et al. 2009). This lifetime refers to the infrastructure only, with the equipment replacements considered as detailed in a subsequent section. For the sludge treatment facilities, the same timeline of 60 years was considered but as their actual lifetime is 30 years (Wang et al. 2008), two plants need to be built over the period. 
The following section gives a brief overview of the treatment techniques considered, followed by a description of the methodology and data used for the estimation of LCC.

\section{$2.2 \quad$ Overview of treatment methods}

Figure 2 shows the advanced wastewater and sludge treatment options considered in the study and where they fit within a WWTP. A brief description of each option is given below, following the overview in Figure 3 and Figure 4, respectively.

\subsubsection{Advanced wastewater treatment}

i) The GAC treatment begins with water pre-coagulation with aluminium sulphate, after which the effluent is passed through GAC columns. The treated effluent is then balanced for $\mathrm{pH}$ and disinfected with chlorine. The spent GAC is regenerated and eventually disposed of in a landfill.

ii) NF relies on membranes to remove contaminants from the effluent. First, the wastewater is passed through a series of pre-filters under high pressure to remove particles and then through the membranes to remove the contaminants. The treated effluent is then balanced for $\mathrm{pH}$ and disinfected. The membranes are cleaned using chemical agents to maintain the pressure drop and the efficiency of treatment; at the end of their useful lifetime they are incinerated.

iii) The SPF process starts with $\mathrm{pH}$ balancing with sulphuric acid, followed by solar-aided catalysis with hydrogen peroxide and iron sulphate. The mixture is left to react in controlled-flux solar panels. The precipitate (mostly iron hydroxide) is removed and landfilled and the effluent is again balanced for $\mathrm{pH}$.

iv) Ozonation uses ozone to decompose contaminants and disinfect the effluent. The ozone is typically produced onsite from air using ozone generators. After the treatment, sodium hydroxide is added to the effluent for $\mathrm{pH}$ balancing.

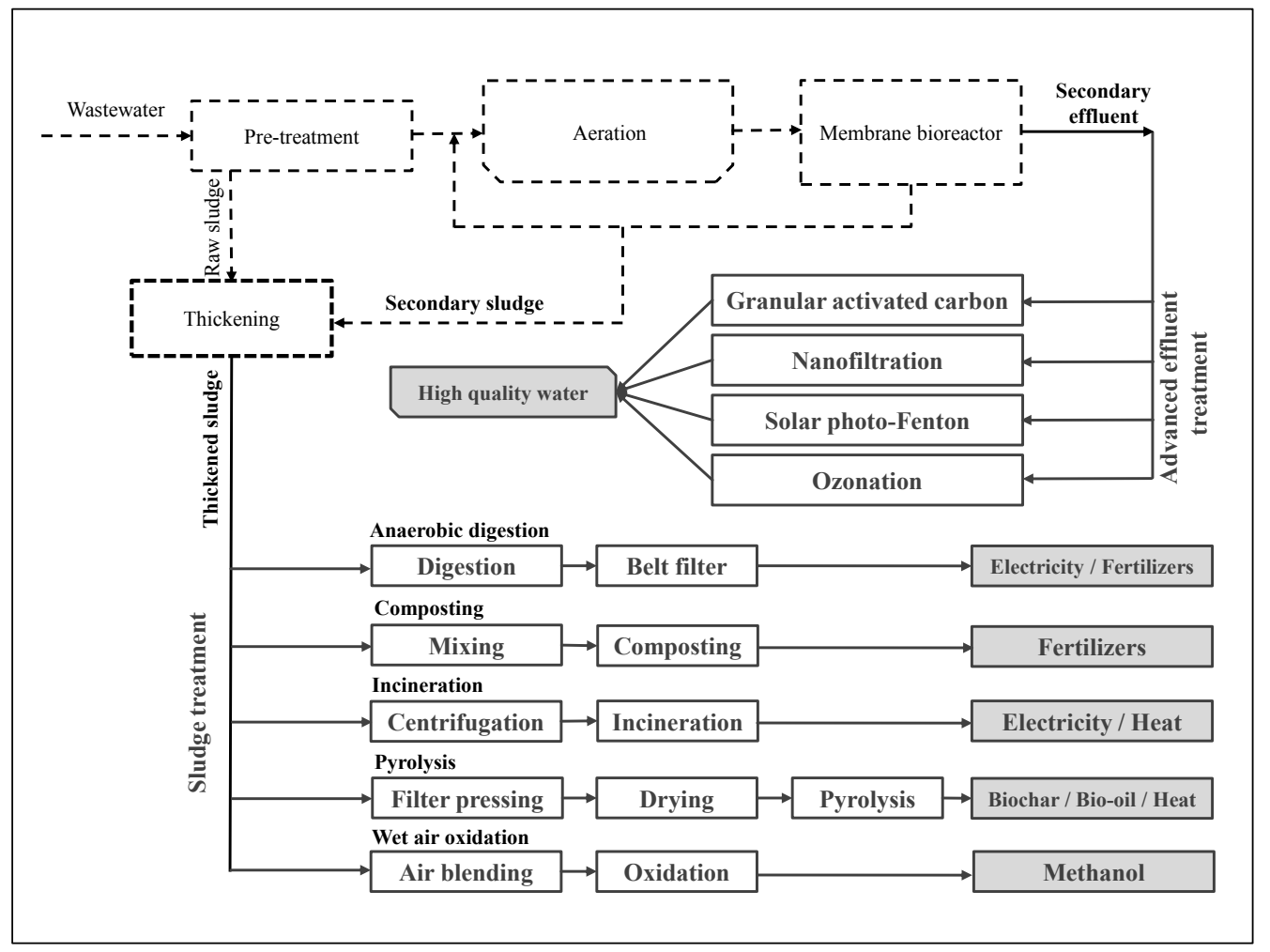

Figure 2 - Overview of the advanced wastewater and sludge treatment techniques considered in the study (Aeration and a membrane bioreactor represent secondary treatment. The dashed lines denote the operations excluded from consideration.) 

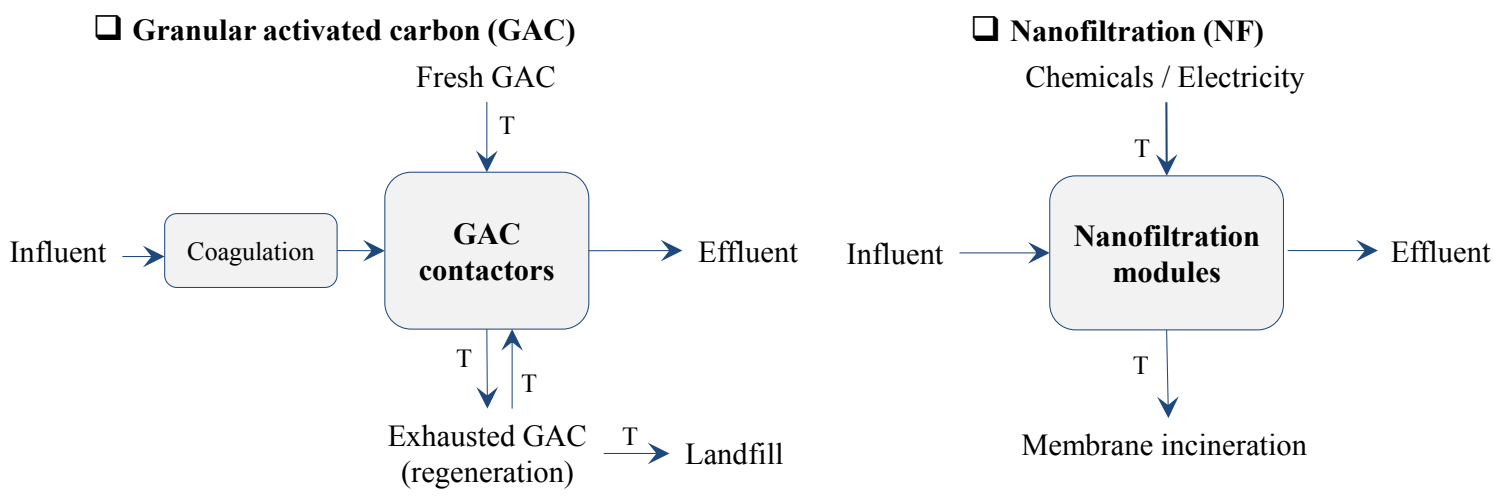

$\square$ Solar photo-Fenton (SPF)

$\square$ Ozonation (OZO)
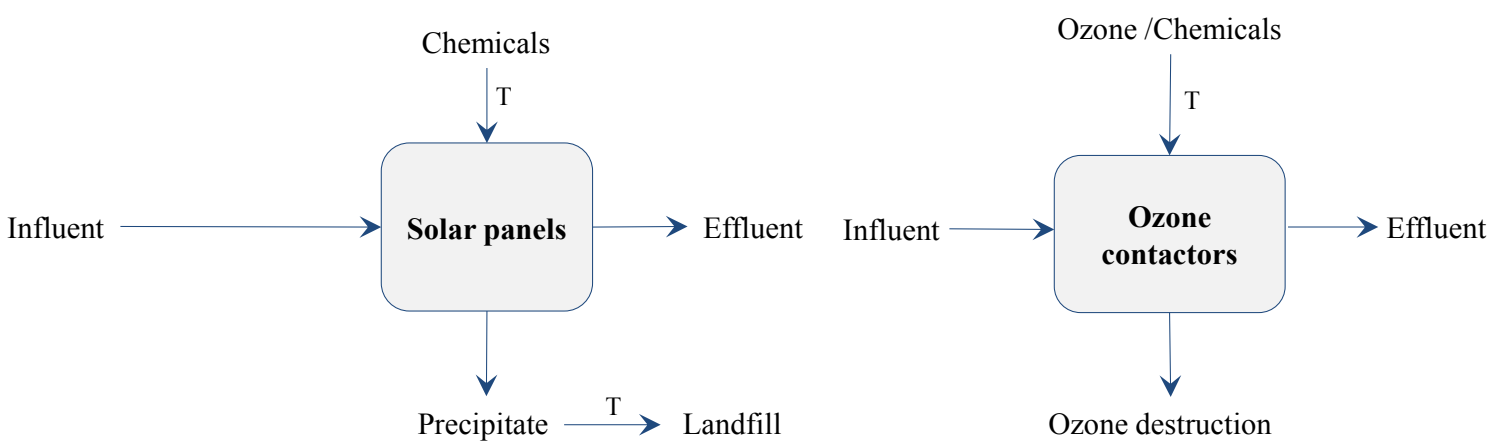

Figure 3 - Overview of the advanced wastewater techniques considered in the study.

Anaerobic digestion of sludge

Thickened sludge

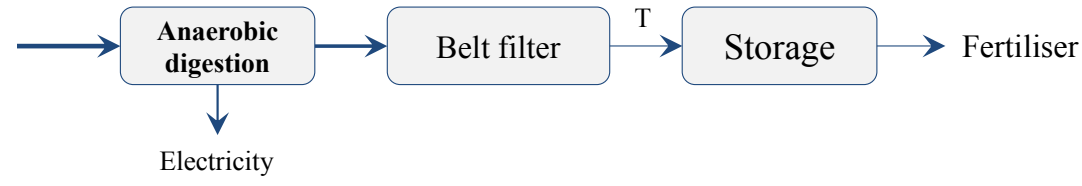

\section{$\square$ Sludge composting}

Thickened sludge

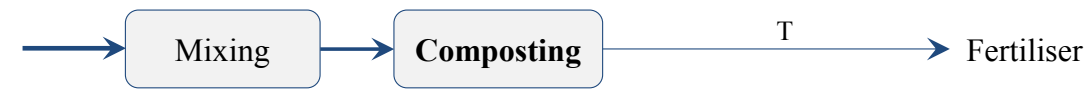

\section{$\square$ Incineration}

Thickened sludge

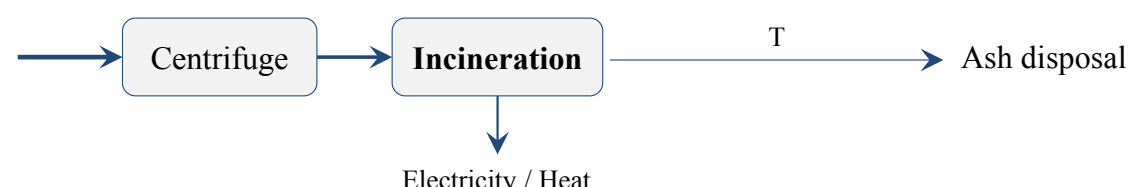

\section{$\square$ Pyrolysis}

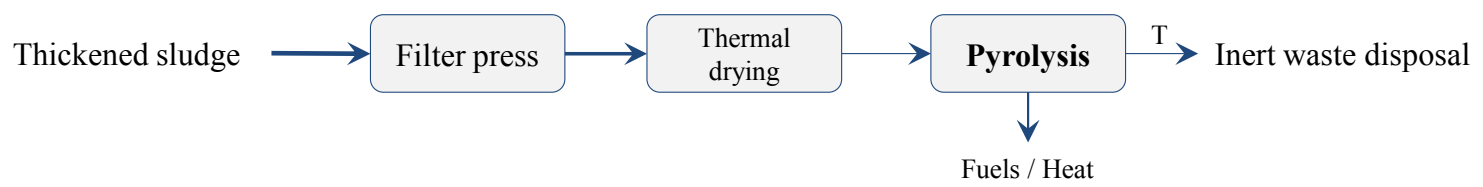

Wet air oxidation

Thickened sludge

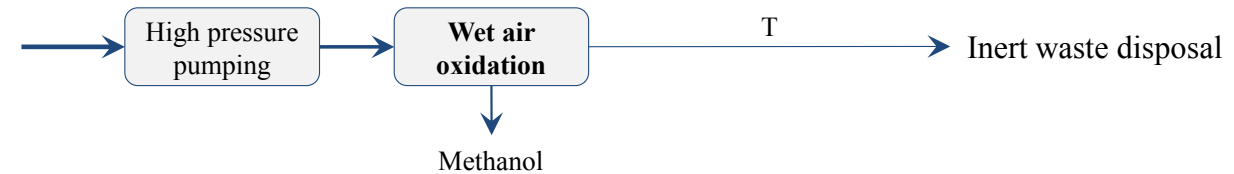

Figure 4 - Overview of the sludge treatment techniques considered in the study. 


\subsubsection{Sludge treatment}

i) Anaerobic digestion of sludge involves anaerobic digestion of sludge, followed by its dewatering in a belt filter. The sludge is then transported and stored at farms prior to land application as fertiliser. Biogas produced in the digester is used to supply the heat to the plant and the excess is burned to generate electricity. The digested sludge is considered to be of high-quality and applied on land following regulations to avoid pathogens contamination and eutrophication of nearby freshwaters (Iranpour et al. 2004, Lu et al. 2012).

ii) Sludge composting is carried out aerobically in a composter, such as an inclined rotating cylinder, normally over the period of one week. Sawdust or another bulking agent is added to the sludge prior to composting to adjust the moisture content and carbon-to-nitrogen ratio. The compost is then transferred to windrows, where it is left for around 12 weeks to complete the composting process. The finished compost is used as soil conditioner. As for the anaerobically digested sludge, the compost is applied onto land following regulations to avoid pathogens contamination and eutrophication (Iranpour et al. 2004, Lu et al. 2012).

iii) Incineration recovers heat and electricity by combusting sludge. To increase the efficiency of energy recovery, before being incinerated the sludge is mixed with a dewatering agent and dewatered in centrifuges. The bottom ash is landfilled and fly ash is stored underground as hazardous waste.

iv) Pyrolysis starts with the dewatering of sludge in a filter press, followed by its thermal drying. The recovered resources are heat, bio-char and bio-oil which can be used to replace natural gas heating, charcoal and fuel oil, respectively. The residual waste is landfilled.

v) Wet air oxidation involves oxidation in a reactor where the sludge is mixed with air at high temperature and pressure. The output of this process is a carbon-rich effluent which can be used as a substitute for methanol in the denitrification process in WWTPs (Houillon \& Jolliet 2005). The residual waste is landfilled.

\subsection{LCC estimation and data}

Following the methodological framework in Swarr et al. (2011), the LCC costs were estimated as follows:

$L C C=C C+I R C+F C+V C+W M C+T C-S \quad$ (£/functional unit $)$

where:

LCC total life cycle costs

CC capital costs

IRC infrastructure replacement costs

FC fixed operating costs

VC variable operating costs (advanced wastewater treatment methods only)

WMC waste management costs

TC transport costs

$\mathrm{S}$ revenue from the sales of recovered products (sludge treatment methods only).

The capital costs $C C$ are the costs of plant infrastructure, including the buildings, equipment and supporting parts; they are detailed in Table 1. The infrastructure replacement costs IRC for the advanced wastewater treatment plants represent the expenditure for replacing the equipment and other supporting infrastructure, assumed to occur every 15 years over the 60 year lifespan. For sludge treatment plants, the IRC refer to the cost of replacing the whole plant after 30 years. 
Equipment replacements in between were not considered due to a lack of data. The $I R C$ are given in Table 2.

Table 1 - Capital costs for the advanced wastewater and sludge treatment techniques

\begin{tabular}{|c|c|c|c|c|c|}
\hline & Treatment & $\begin{array}{l}\text { Capital costs } \\
\text { (million } \mathfrak{f} \text { ) }\end{array}$ & Included & Excluded & Source \\
\hline \multirow{4}{*}{ 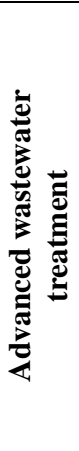 } & $\begin{array}{l}\text { Granular activated } \\
\text { carbon }^{\text {a }}\end{array}$ & $0.41^{\mathrm{e}, \mathrm{f}}$ & $\begin{array}{l}\text { Contactors, pipes and pumps, } \\
\text { electrical equipment }\end{array}$ & Pre-coagulation tanks & $\begin{array}{l}\text { Wang et al. } \\
(2005)\end{array}$ \\
\hline & Nanofiltration ${ }^{b}$ & $3.73^{\mathrm{e}, \mathrm{f}}$ & $\begin{array}{l}\text { High-pressure pumps, pressure tubes and support, } \\
\text { diaphragms and joints, piping and taps, electrical } \\
\text { equipment and installations }\end{array}$ & $\begin{array}{l}\text { Treatment of the } \\
\text { concentrate }^{g}\end{array}$ & $\begin{array}{l}\text { Elazhar et } \\
\text { al. (2009) }\end{array}$ \\
\hline & $\begin{array}{l}\text { Solar photo- } \\
\text { Fenton }^{c}\end{array}$ & $9.34^{\mathrm{e}, \mathrm{f}}$ & Solar panels and control equipment & Precipitate separation & $\begin{array}{l}\text { Muñoz } \\
(2006)\end{array}$ \\
\hline & Ozonation $^{\mathrm{d}}$ & $2.63^{\mathrm{e}, \mathrm{f}}$ & $\begin{array}{l}\text { Air preparation, ozone generation units, contactors } \\
\text { with diffusers, monitoring equipment, ozone } \\
\text { destruction unit }\end{array}$ & - & $\begin{array}{l}\text { Wang et al. } \\
(2005)\end{array}$ \\
\hline \multirow{5}{*}{ 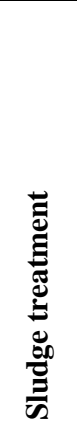 } & $\begin{array}{l}\text { Anaerobic } \\
\text { digestion }\end{array}$ & $2.87^{\mathrm{e}, \mathrm{f}}$ & Anaerobic digesters and belt filter & $\begin{array}{l}\text { Machinery for land } \\
\text { application and storage } \\
\text { facility }\end{array}$ & $\begin{array}{l}\text { Hung et al. } \\
\text { (2013) }\end{array}$ \\
\hline & Composting & $1.47^{\mathrm{e}, \mathrm{f}}$ & Aerated composting facility & $\begin{array}{l}\text { Machinery for land } \\
\text { application }\end{array}$ & $\begin{array}{l}\text { Hung et al. } \\
(2013)\end{array}$ \\
\hline & Incineration & $2.33^{\mathrm{e}, \mathrm{f}}$ & Centrifuge and incinerator & & $\begin{array}{l}\text { Hung et al. } \\
\text { (2013) }\end{array}$ \\
\hline & Pyrolysis & $3.38^{\mathrm{e}, \mathrm{f}}$ & Filter press, thermal dryer and pyrolysis unit & - & $\begin{array}{l}\text { Hung et al. } \\
\text { (2013) }\end{array}$ \\
\hline & Wet air oxidation & $3.59^{\mathrm{e}, \mathrm{f}}$ & Wet air oxidation plant & - & $\begin{array}{l}\text { Hung et al. } \\
(2013)\end{array}$ \\
\hline
\end{tabular}

${ }^{\mathrm{a}}$ Estimated from a two-stage granular activated carbon system configuration.

${ }^{\mathrm{b}}$ Estimated for a facility with 1,866 nanofiltration membranes.

${ }^{\mathrm{c}}$ Estimated using the economies of scale relationship (the 'six tenths' rule) and a 30 minutes residence period in the solar panels.

${ }^{\mathrm{d}}$ Estimated from small scale treatment plants $\left(<2,000 \mathrm{~m}^{3} / \mathrm{d}\right)$.

${ }^{\mathrm{e}}$ Values updated to 2018 considering a $3 \%$ annual inflation in the UK.

${ }^{\mathrm{f}}$ Exchange ratios: US Dollar to British Pound (2005): 1.88; US Dollar to British Pound (2013): 1.95; Euro to British Pound (2006):

1.45; Euro to British Pound (2009): 1.10. Source: poundsterlinglive (2018).

${ }^{\mathrm{g}}$ Assumed to be recycled back to the conventional wastewater treatment process.

Table 2 - Infrastructure replacement costs for the advanced wastewater and sludge treatments over their lifespan ${ }^{\mathrm{a}}$

\begin{tabular}{lc}
\hline Treatment & $\begin{array}{c}\text { Infrastructure replacement costs } \\
\text { (million } \mathfrak{E})\end{array}$ \\
\hline Granular activated carbon & 1.22 \\
Nanofiltration & 11.19 \\
Solar photo-Fenton & 28.02 \\
Ozonation & 7.90 \\
Anaerobic digestion & 2.87 \\
Composting & 1.47 \\
Incineration & 2.33 \\
Pyrolysis & 3.38 \\
Wet air oxidation & 3.59 \\
\hline
\end{tabular}

${ }^{\mathrm{a}}$ The lifespan of all advanced wastewater plants is 60 years, with the replacement period of 15 years, except for granular activated carbon (110-330 days; see Table A1 in the Appendix) and nanofiltration membranes (a range of values considered: $\mathrm{min} / \mathrm{mean} / \mathrm{max}=$ $5 / 10 / 15$ years). For the sludge treatment, the total lifespan is 30 years so that the whole plant is replaced after 30 years; no equipment replacements were considered in between.

The fixed operating costs $F C$ relate to the cost of materials and energy which are used regardless of the level of treatment of water or sludge (e.g. electricity for pumping or a dewatering agent). On the other hand, the variable operating costs $V C$ refer to the materials and energy whose usage varies depending on the level of wastewater treatment needed to obtain a certain quality of the effluent; thus, these costs are only applicable to the wastewater treatment methods. The data for the operating 
parameters for the wastewater plants can be found in Table 3 and for sludge processing in Table 4; the corresponding $F C$ and $V C$ are detailed in Table 5-Table 7. To account for the uncertainty in the sourcing (origin) of different materials and chemicals, both UK production and imports from China were considered, the latter being a significant exporter of goods worldwide. As can be seen in Table 5 , there is a large difference between the costs in the respective countries so that the average values were used for the estimation in the base case; the effect of these differences on the LCC was considered in a sensitivity analysis.

Table 3 - Operating, waste management and transport data for the advanced effluent treatment plants (per $1,000 \mathrm{~m}^{3}$ of secondary effluent)

\begin{tabular}{|c|c|c|c|c|c|}
\hline Item & $\begin{array}{c}\text { Granular activated } \\
\text { carbon }\end{array}$ & Nanofiltration & $\begin{array}{c}\text { Solar } \\
\text { photo-Fenton }\end{array}$ & Ozonation & $\begin{array}{c}\text { Unit } \\
\left(\text { per } 1,000 \mathrm{~m}^{3}\right) \\
\end{array}$ \\
\hline \multicolumn{6}{|l|}{ Fixed operating parameters } \\
\hline Electricity & $29^{\mathrm{d}}$ & & & & $\mathrm{kWh}$ \\
\hline Aluminium sulphate (powder) & $80^{\mathrm{d}}$ & & & & $\mathrm{kg}$ \\
\hline Calcium hydroxide & $7.0^{\mathrm{d}}$ & $31^{\mathrm{d}}$ & & & $\mathrm{kg}$ \\
\hline Carbon dioxide, liquid & $14^{\mathrm{d}}$ & $31^{\mathrm{d}}$ & & & $\mathrm{kg}$ \\
\hline Chlorine, liquid & $0.60^{\mathrm{d}}$ & $0.6^{\mathrm{d}}$ & & & $\mathrm{kg}$ \\
\hline Phosphoric acid & $1.10^{\mathrm{d}}$ & & & & $\mathrm{kg}$ \\
\hline Polymer (dewatering aid) & $0.30^{\mathrm{d}}$ & & & & $\mathrm{kg}$ \\
\hline Sodium hydroxide & $60^{\mathrm{d}}$ & & $80^{\mathrm{f}}$ & $80^{\mathrm{f}}$ & $\mathrm{kg}$ \\
\hline Sulphuric acid & & $36^{\mathrm{d}}$ & $130^{\mathrm{f}}$ & & $\mathrm{kg}$ \\
\hline \multicolumn{6}{|l|}{ Variable operating parameters ${ }^{\mathrm{a}}$} \\
\hline Electricity & & $270 / 412 / 554^{\mathrm{d}}$ & & $150 / 750 / 1,300^{\mathrm{i}}$ & $\mathrm{kWh}$ \\
\hline $\begin{array}{l}\text { Ethylenediaminetetraacetic acid } \\
\text { (EDTA) }\end{array}$ & & $0.16 / 0.25 / 0.34^{\mathrm{d}}$ & & & $\mathrm{kg}$ \\
\hline Fresh granular activated carbon & $5 / 11 / 22^{\mathrm{g}}$ & & & & $\mathrm{kg}$ \\
\hline $\begin{array}{l}\text { Regenerated granular activated } \\
\text { carbon }\end{array}$ & $25 / 55 / 110^{\mathrm{g}}$ & & & & $\mathrm{kg}$ \\
\hline Hydrogen peroxide & & & $20 / 110 / 200^{\mathrm{f}}$ & & $\mathrm{kg}$ \\
\hline Iron sulphate & & & $14 / 34 / 55^{\mathrm{f}}$ & & $\mathrm{kg}$ \\
\hline Sodium hydroxide & & $0.16 / 0.25 / 0.34^{\mathrm{d}}$ & & & $\mathrm{kg}$ \\
\hline Spiral-wound membranes & & $0.0053 / 0.008 / 0.160^{\mathrm{h}}$ & & & membrane \\
\hline \multicolumn{6}{|l|}{ Waste management } \\
\hline Incineration (waste) & & $0.36^{\mathrm{d}, \mathrm{e}}$ & & & $\mathrm{kg}$ \\
\hline Landfill (sanitary) & $5 / 11 / 22$ & & 46 & & $\mathrm{~kg}$ \\
\hline \multicolumn{6}{|l|}{ Transport $^{b, c}$} \\
\hline 16-32 tonne lorry & 44 / 57 / 81 & 20 & $58 / 80$ / 102 & 16 & t.km \\
\hline
\end{tabular}

${ }^{a}$ Minimum/mean/maximum values where shown.

${ }^{\mathrm{b}}$ Over the lifetime of the plant.

${ }^{\mathrm{c}}$ Transport distances assumed at $200 \mathrm{~km}$, except for fresh granular activated carbon $(1,000 \mathrm{~km})$ as it is imported from Germany. Transport of spiral-wound membranes to the treatment plant is not included.

${ }^{\mathrm{d}}$ Data from Bonton et al. (2012) and/or Cyna et al. (2002).

${ }^{\mathrm{e}}$ Variation in the incinerated weight for different membrane's lifetime assumed negligible.

${ }^{\mathrm{f}}$ Data based on Klamerth (2011), Trovó et al. (2013), Ribeiro et al. (2015) and Muñoz et al. (2007).

${ }^{\mathrm{g}}$ The needed amount GAC was estimated considering a maximum of 10 regeneration cycles every 110 to 330 days, with a $10 \%$ loss in each cycle; for details, see Table A1 in the Appendix.

${ }^{\mathrm{h}}$ Data on membrane use sourced from Bonton et al. (2012) and Elazhar et al. (2009). Membrane replacement periods: $\mathrm{min} / \mathrm{mean} / \mathrm{max}$ $=5 / 10 / 15$ years.

${ }^{\mathrm{i}}$ Electricity consumption to generate ozone assumed at $16.5 \mathrm{kWh} / \mathrm{kg}$ ozone. For ozone dosage and transfer efficiencies, see Table A1 in the Appendix.

The costs of waste management WMC include landfilling and incineration of waste and they are shown in Table 8, together with the transportation costs $T C$, which include transport of materials, chemicals and wastes; transport of recovered resources to the point of sale is excluded. The infrastructure for heat and electricity distribution is also excluded as that is already in existence regardless of sludge treatment.

The sludge treatment plants were credited for the revenue $S$ from the sales of recovered resources, based on their amounts (Table 4) and the market prices of the products that they potentially replace (Table 9). The water treatment plants were not credited for a potential revenue from selling tap water as wastewater is currently not used for this purpose in the UK. In addition, new infrastructure 
would be required to enable distribution of tap water from wastewater treatment plants to the potable distribution network and the cost data for this were not available. There are also regulatory and consumer perception issues which would need to be resolved before wastewater can be reclaimed as tap water. By contrast, the recovery of resources from sludge is well established and most of the co-products are used commercially, including in agriculture and for energy supply.

As some operating parameters vary significantly for some of the treatment methods, a range of values were considered as specified in Table 3. The amount of the recovered resources sold was also varied, ranging from complete to no sale of products (see Table 4). Labour costs for the operation of the plants were not included as it was assumed that they were similar across the methods considered, given that they would be integrated within a conventional WWTP. However, it is acknowledged that some of the methods may incur higher labour costs due to the need for a specialised workforce or more intensive maintenance. As mentioned earlier, the decommissioning costs were also excluded due to their uncertainty over the 60 -year period. For the same reasons, the end-of-life value of the facility was not considered either.

Table 4 - Operating parameters, waste management, recovered products and transport data for the sludge treatment plants

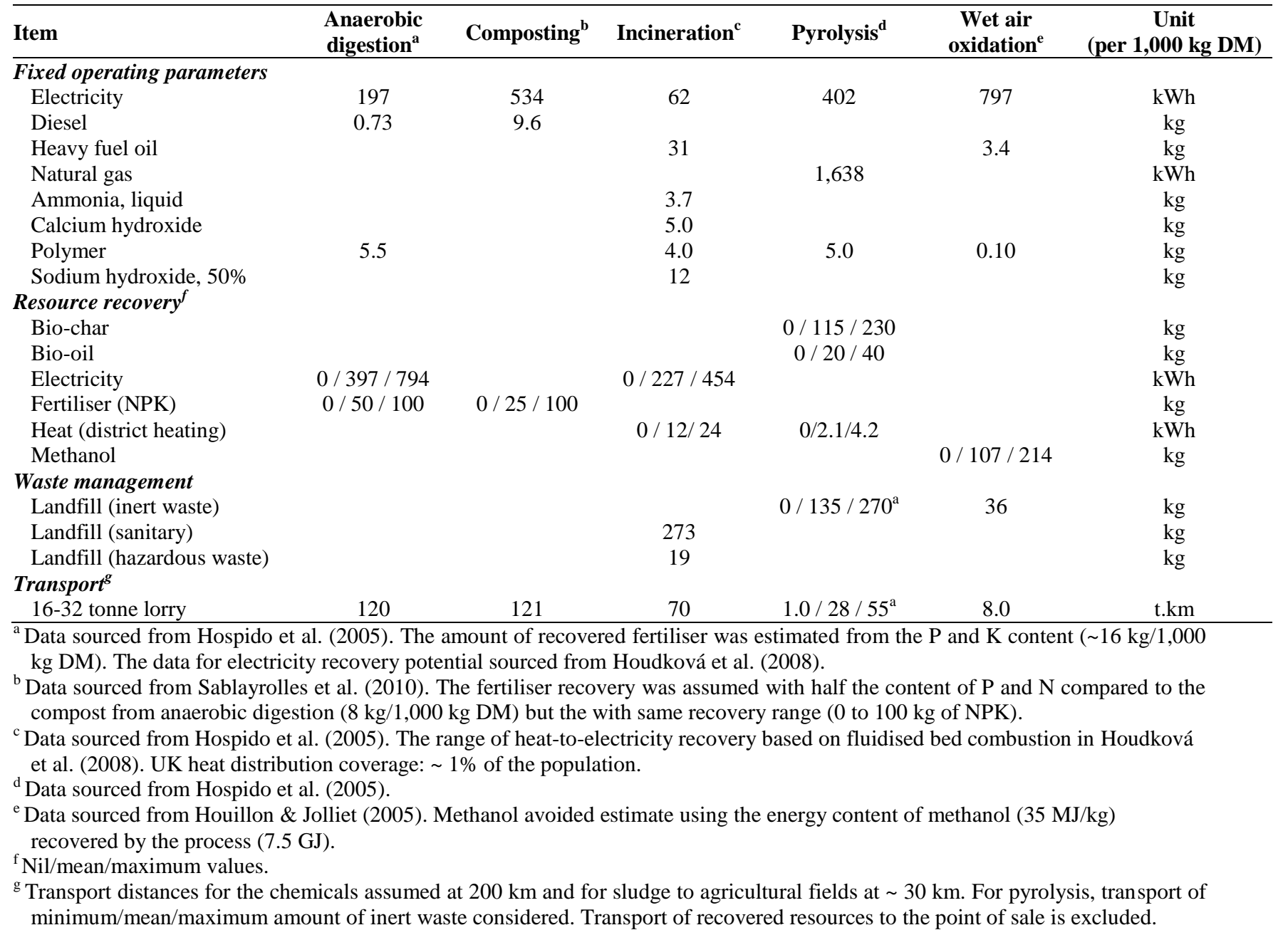


Table 5 - Prices of chemicals in the UK and imports from China ${ }^{\mathrm{a}}$

\begin{tabular}{|c|c|c|c|c|}
\hline & \multicolumn{3}{|c|}{ Price (£/kg) } & \multirow[t]{2}{*}{ Source } \\
\hline & UK & Imports from China & Mean & \\
\hline Aluminium sulphate (granules) & 1.95 & 0.30 & 1.13 & Easychemtrade (2016), Shandong Sanfeng group (2016) \\
\hline Ammonia (liquid) & 1.70 & 0.50 & 1.10 & ReAgent (2016), Shijiazhuang Xinlongwei Chemical (2016) \\
\hline Calcium hydroxide (powder) & 1.32 & 0.25 & 0.79 & $\begin{array}{l}\text { Mistral Industrial Chemicals (2016), Guangdong Qiangda } \\
\text { New Materials Technology (2016) }\end{array}$ \\
\hline Carbon dioxide, liquid & 1.75 & 0.30 & 1.03 & $\begin{array}{l}\text { Gas UK (2016), Anqiu Hengan Gas Manufacture Factory } \\
\text { (2016) }\end{array}$ \\
\hline Chlorine & 1.50 & 0.50 & 1.00 & Alliance UK (2016), Qingdao Huatuo Chemical (2016) \\
\hline $\begin{array}{l}\text { Ethylenediaminetetraacetic acid } \\
\text { (EDTA), powder }\end{array}$ & 4.90 & 2.00 & 3.45 & $\begin{array}{l}\text { Mistral Industrial Chemicals (2016), Jinan Yuxing Chemical } \\
\text { (2016) }\end{array}$ \\
\hline Hydrogen peroxide & 0.90 & 0.60 & 0.75 & Easychemtrade (2016), Zhengzhou Qiangjin (2016) \\
\hline Iron sulphate (powder) & 1.20 & 0.40 & 0.80 & $\begin{array}{l}\text { Mistral Industrial Chemicals (2016), Zhuzhou Rongda } \\
\text { Chemical (2016) }\end{array}$ \\
\hline Phosphoric acid & 1.68 & 0.85 & 1.27 & $\begin{array}{l}\text { Easychemtrade (2016), Guangxi Qinzhou Capital Chemical } \\
\text { (2016) }\end{array}$ \\
\hline Polymer (granules) & 1.60 & 0.85 & 1.23 & $\begin{array}{l}\text { British Plastics Federation (2016), Hebei Xiongye Machine } \\
\text { Trade (2016) }\end{array}$ \\
\hline Sodium hydroxide & 0.36 & 0.25 & 0.31 & Easychemtrade (2016), Qingdao Huatuo Chemical (2016) \\
\hline Sulphuric acid & 0.45 & 0.35 & 0.40 & $\begin{array}{l}\text { Easychemtrade (2016), Wuhan Guotai Hongfa Commodity } \\
\text { (2016) }\end{array}$ \\
\hline
\end{tabular}

${ }^{a}$ Costs of Chinese supplies were estimated from their average costs and shipping to the UK, the latter at a rate of £200/t (World Freight Rates 2016). The exchange rate: 100 Chinese Yuan $=£ 11.5$.

Table 6 - Energy prices ${ }^{\mathrm{a}}$

\begin{tabular}{|c|c|c|c|c|}
\hline \multirow{2}{*}{$\frac{\text { Item }}{\text { Diesel }}$} & \multicolumn{4}{|c|}{ Price (£/unit) } \\
\hline & 1.20 & 1.40 & 1.30 & $\mathrm{~kg}$ \\
\hline Electricity & 0.08 & 0.12 & 0.10 & $\mathrm{kWh}$ \\
\hline Heavy fuel oil & ${ }^{b} 0.48$ & 0.64 & 0.56 & $\mathrm{~kg}$ \\
\hline Natural gas & 0.02 & 0.04 & 0.03 & $\mathrm{kWh}$ \\
\hline
\end{tabular}

${ }^{2}$ Source: Department of Energy and Climate Change (2015).

${ }^{\mathrm{b}}$ Used in incineration and recovered as a product in pyrolysis.

Table 7 - Prices of granular activated carbon and nanofiltration membranes

\begin{tabular}{|c|c|c|c|c|c|c|}
\hline & \multicolumn{3}{|c|}{ Price $^{\mathrm{a}}$ (£/unit) } & \multirow{2}{*}{-Unit } & \multirow{2}{*}{ Comment } & \multirow{2}{*}{ Source } \\
\hline & Minimum & Maximum & Average & & & \\
\hline Granular activated carbon (fresh) & 1.20 & 1.60 & 1.40 & $\mathrm{~kg}$ & - & $\begin{array}{l}\text { Chengde Hongya Activated Carbon } \\
\text { (2016), Jeswani et al. (2015) }\end{array}$ \\
\hline $\begin{array}{l}\text { Granular activated carbon } \\
\text { (regeneration) }\end{array}$ & 0.60 & 0.80 & 0.70 & $\mathrm{~kg}$ & - & Jeswani et al. (2015), Bayer et al. (2005) \\
\hline Spiral-wound membrane & 450 & 610 & 530 & module & $\begin{array}{l}\text { NF90-8040/ } \\
\text { NF270-400 }\end{array}$ & Elazhar et al. (2009) , ServApure (2016) \\
\hline
\end{tabular}

${ }^{\text {a }}$ Values corrected to 2018 considering a $3 \%$ annual inflation in the UK

${ }^{\mathrm{b}}$ Exchange ratio Euro to British Pound in 2009: 1.10 (poundsterlinglive (2018).

Table 8 - Costs of waste disposal and transport

\begin{tabular}{llll}
\hline Item & $\begin{array}{l}\text { Cost } \\
(\mathfrak{f} / \mathbf{u n i t})\end{array}$ & Unit & Source \\
\hline Incineration (waste) & 90.0 & $\mathrm{t}$ & WRAP (2013) \\
Landfill (inert) & 25.0 & $\mathrm{t}$ & WRAP (2013) \\
Landfill (sanitary) & 35.0 & $\mathrm{t}$ & WRAP (2013) \\
Landfill (hazardous) & 84.4 & $\mathrm{t}$ & WRAP (2013) \\
Transport & 0.29 & t.km & Spielmann et al. (2007) \\
\hline
\end{tabular}


Table 9 - Market prices of products replaced by the equivalent resources recovered by sludge treatment

\begin{tabular}{lllll}
\hline & $\begin{array}{l}\text { Average } \\
\text { price } \\
(£ / \text { Unit })\end{array}$ & Unit & Comment & Source \\
\hline Charcoal & 1.78 & $\mathrm{~kg}$ & Made from wood & $\begin{array}{l}\text { Ganzhou Green Top Biological Technology (2016), } \\
\text { Treewood (2016) }\end{array}$ \\
$\begin{array}{l}\text { District heating } \\
\text { Methanol }\end{array}$ & 0.10 & $\mathrm{kWh}$ & Heating from diverse sources & $\begin{array}{l}\text { WHICH? (2015) } \\
\text { Shijiazhuang City Horizon Chemical (2016), ReAgent } \\
(2016)\end{array}$ \\
$\begin{array}{l}\text { Synthetic } \\
\text { fertiliser }\end{array}$ & 0.75 & $\mathrm{~kg}$ & - & $\begin{array}{l}\text { Zouping Runzi Chemical Industry (2016), Agroshop } \\
(2016)\end{array}$ \\
\hline
\end{tabular}

\section{Results and discussion}

The life cycle costs of the wastewater and sludge treatment methods are summarised in Figure 5 and Figure 6, respectively, showing the contribution of different life cycle stages and the range of costs, depending on the assumptions for the operating variables and the sale of the recovered resources. The results are discussed in the next sections, first for the wastewater and then for the sludge treatment techniques. The discussion refers to the mean values of the parameters in Table 3 and Table 4, respectively.

\subsection{Advanced effluent treatment}

As can be seen in Figure 5, the lowest LCC were found for ozonation $\left(£ 112 / 1,000 \mathrm{~m}^{3}\right)$ and the highest for SPF $\left(£ 238 / 1,000 \mathrm{~m}^{3}\right)$, followed closely by GAC $\left(£ 205 / 1,000 \mathrm{~m}^{3}\right)$. The mean costs of NF are estimated at $£ 134 / 1,000 \mathrm{~m}^{3}$. However, taking into account the variation in their operating parameters (see Table 3) the GAC costs in the best case $\left(£ 171 / 1,000 \mathrm{~m}^{3}\right)$ approach the costs of ozonation at its worst operating conditions (£167). In the best case, the costs of SPF $(£ 148 / 1,000$ $\mathrm{m}^{3}$ ) are also comparable with the maximum NF costs (£153). However, ozonation is by far the cheapest option assuming its best performance, costing only $£ 52 / 1,000 \mathrm{~m}^{3}$.

As also shown in Figure 5, the main contributor to the total LCC are the operating costs ( $\sim 80 \%$ $90 \%$ ) for all the treatment methods. On average, GAC and SPF are the most costly to operate $\left(\sim £ 187 / 1,000 \mathrm{~m}^{3}\right)$ and ozonation is the least expensive (£100). For GAC, $45 \%$ of the total cost is due to aluminium sulphate used for coagulation (Figure 7) and $20 \%$ due to the other chemicals used in the process. The regeneration of the spent carbon contributes $18 \%$ to the total, with the cost of the fresh adsorbent adding a further $7 \%$. In the case of SPF, hydrogen peroxide represents $38 \%$ of the total costs and iron sulphate (catalyst) $13 \%$. For NF, chemicals account for $50 \%$, electricity $~ 30 \%$ and the membranes only $3 \%$ of the total LCC. The majority of the costs for ozonation are due to electricity $(65 \%)$ and sodium hydroxide $(20 \%)$.

Transport costs are significant (contributing $\geq 10 \%$ to total LCC) only for GAC and SPF. For the former, this is due to the transport of fresh GAC which is imported from Germany and for the latter because of the relatively large quantity of chemicals that need to be transported to the plant. The construction, infrastructure replacements and waste management costs have a minor contribution to the total LCC for GAC. SPF is the most expensive plant to build $\left(£ 6.7 / 1,000 \mathrm{~m}^{3}\right)$, followed by NF $\left(£ 2.7 / 1,000 \mathrm{~m}^{3}\right)$. 


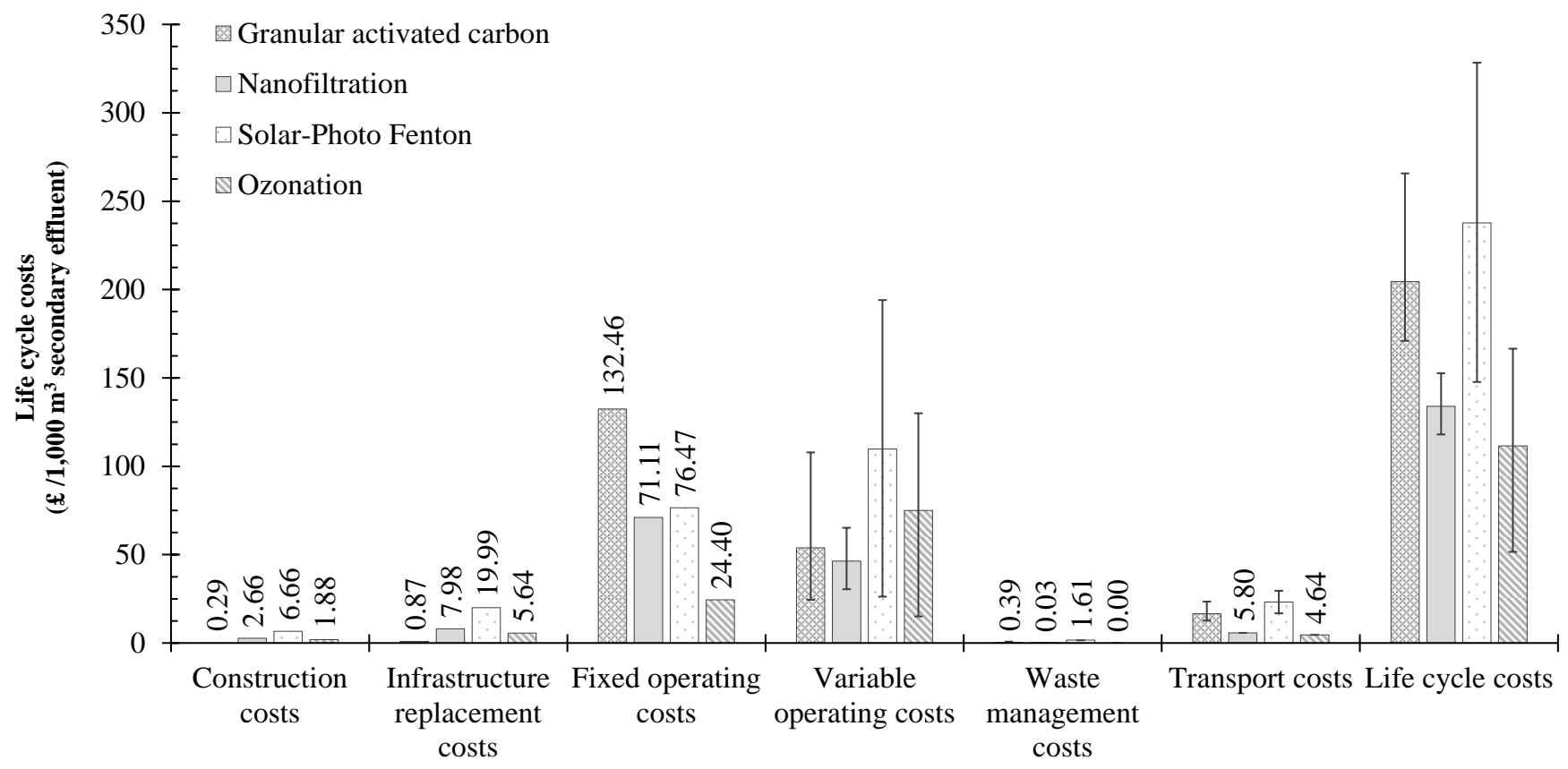

Figure 5 - Life cycle costs of the advanced effluent treatment techniques showing the contribution of different stages (The data labels represent the costs for the mean and the error bars for the minimum and maximum values of the parameters in Table 3).

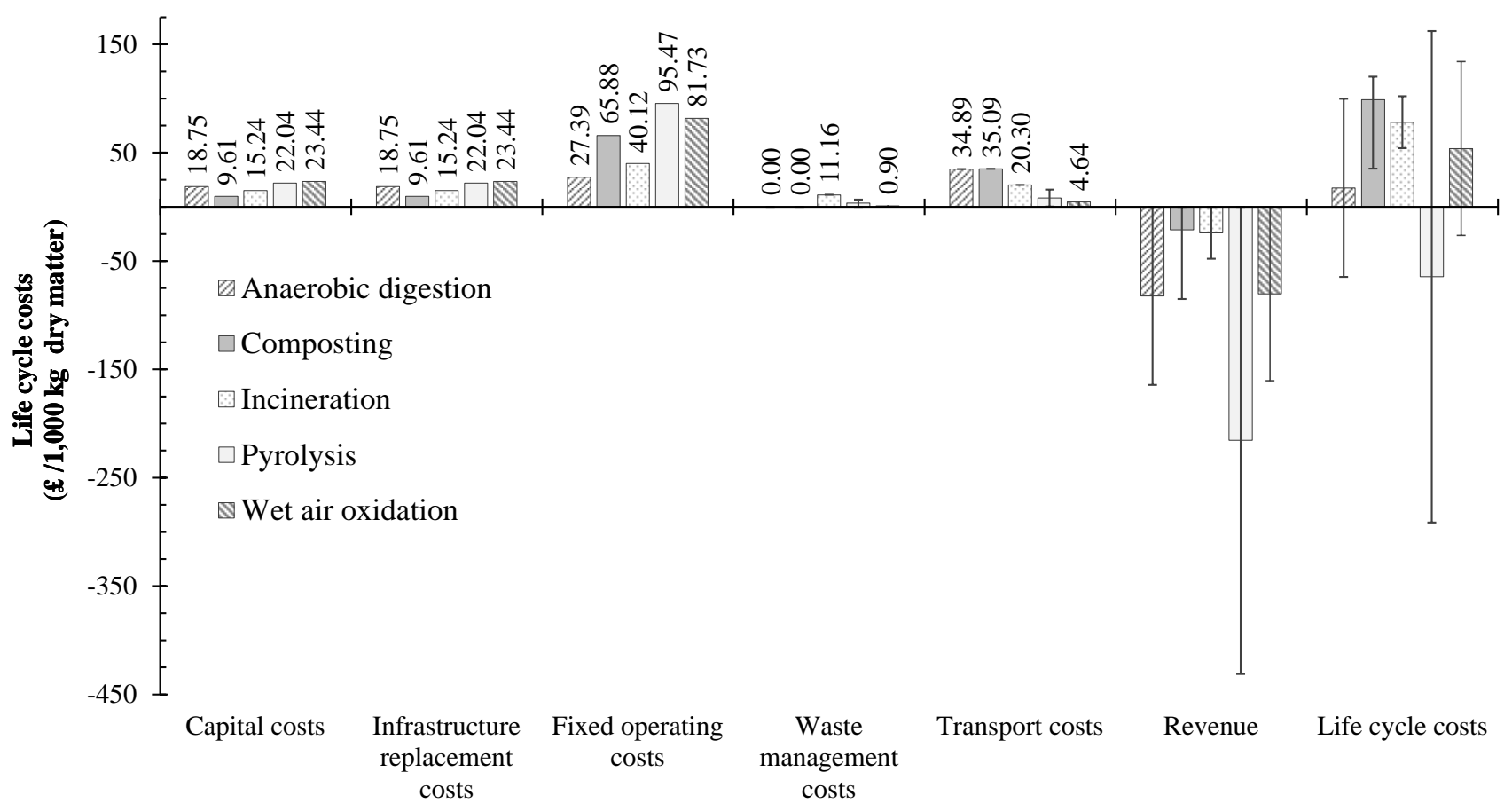

Figure 6 - Life cycle cost of sludge treatment techniques showing the contribution of different stages (Revenue refers to the income from recovered product(s). The data labels represent the costs for the mean and the error bars for the minimum and maximum values of the parameters in Table 4). 


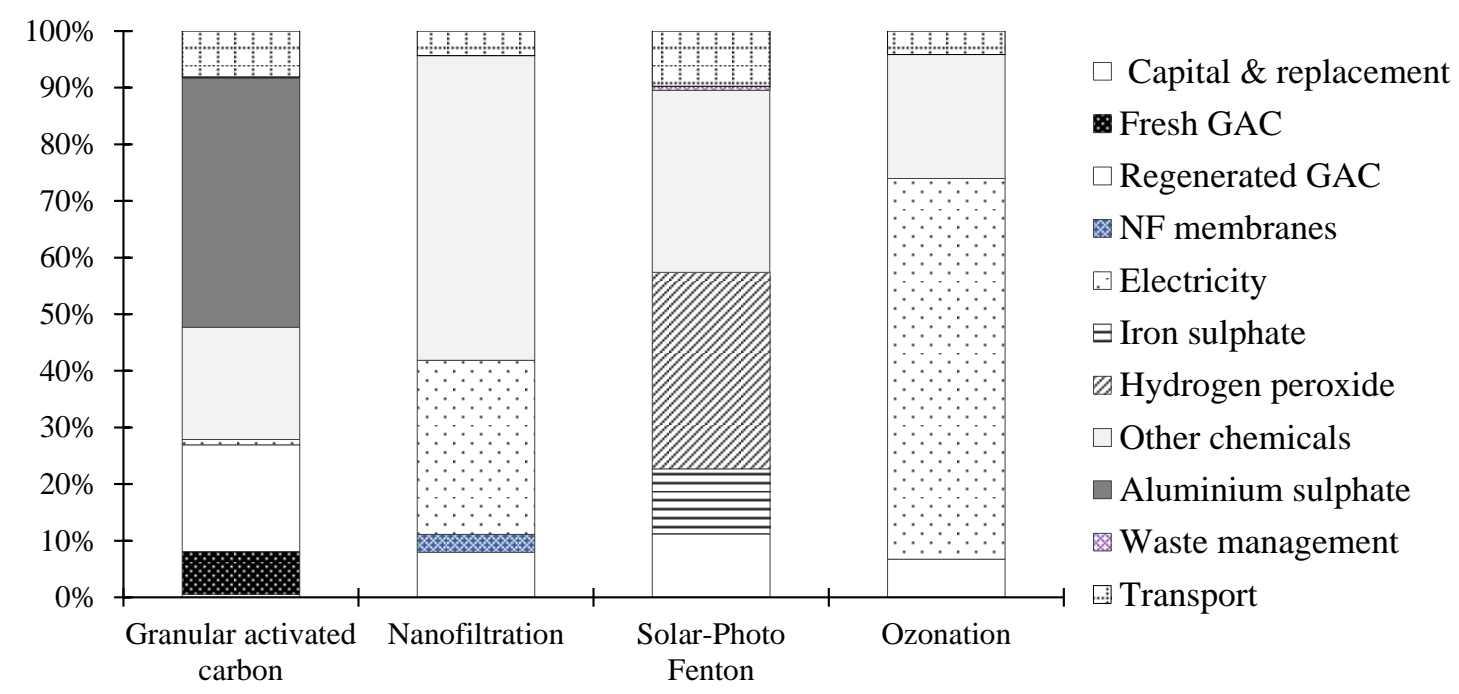

Figure 7 - Contribution of different life cycle stages to the costs of advanced wastewater treatment plants for the mean operating parameters (For the latter, see Table 3).

\subsection{Sludge treatment}

For the mean amount of recovered products, pyrolysis is the best sludge treatment option with an overall negative LCC, or a net profit of $£ 64.5$ per $1,000 \mathrm{~kg}$ dry matter (DM); see Figure 6. Anaerobic digestion is the next least costly alternative with $£ 17.6$, followed by wet air oxidation at $£ 53.9$. Composted sludge is the most expensive method with the costs estimated at $£ 98.9 / 1,000 \mathrm{~kg}$ DM. However, the costs vary widely, particularly for anaerobic digestion and pyrolysis, depending on the assumptions for the sales of the recovered products. For example, in the best case for pyrolysis, its profit increases more than four-fold, from $£ 64.5$ to $£ 291 / 1,000 \mathrm{~kg} \mathrm{DM}$, but in the worst case its LCC costs are equal to $£ 162 / 1,000 \mathrm{~kg}$. For anaerobic digestion, the LCC values range from around -£64.6 to around $£ 99.8$ per $1,000 \mathrm{~kg}$ DM.

Assuming the least favourable conditions for composting, its costs reach $£ 120.2$ but are still below those of wet air oxidation ( $£ 134)$ at similar conditions. For the maximum recovery of fertiliser value from sludge, the costs of composting reduce to $£ 35.2 / 1,000 \mathrm{~kg}$ DM. The LCC for incineration in the best case with complete recovery of products (£54.3) are comparable to the mean costs of wet air oxidation, at $£ 53.9 / 1,000 \mathrm{~kg}$ DM. The latter can achieve negative LCC costs (profit) of $-£ 26.4$ at the most favourable conditions.

Like the wastewater treatment techniques, the operating costs are also the main contributor to the LCC of the sludge handling methods (Figure 8), with a greater share for composting $(>80 \%)$ than for the other options ( 40\%-80\%). The capital and infrastructure replacement costs are also significant, adding between $15 \%$ and $30 \%$ to the total. Pyrolysis and wet air oxidation are the most expensive plants to build ( $£ 22$ and $£ 23.4 / 1,000 \mathrm{~kg} \mathrm{DM}$ ). Transport is the most significant for the digested sludge and compost, contributing 20\%-25\%, mainly due to their transport to the farm. It also contributes $18 \%$ to the costs of incineration because of the transport of ash to disposal. Waste management costs are insignificant for most options except for incineration, where they contribute $10 \%$. This suggests that the additional costs of managing waste are low, which in itself should be an incentive. However, the other costs are higher, so other, external incentives would be needed for the whole system, not just for the waste management part of the life cycle.

As indicated in Figure 8, electricity is an important cost factor for all the alternatives, contributing from $10 \%$ in the digested sludge system to over $40 \%$ in wet air oxidation. The only exception to this is incineration where it contributes around $5 \%$ to the total. The costs of natural gas for sludge drying 
are notable for pyrolysis, contributing nearly $15 \%$. The revenue from the recovered products reduces the costs on average by $15 \%$ to $60 \%$ across the treatment options.

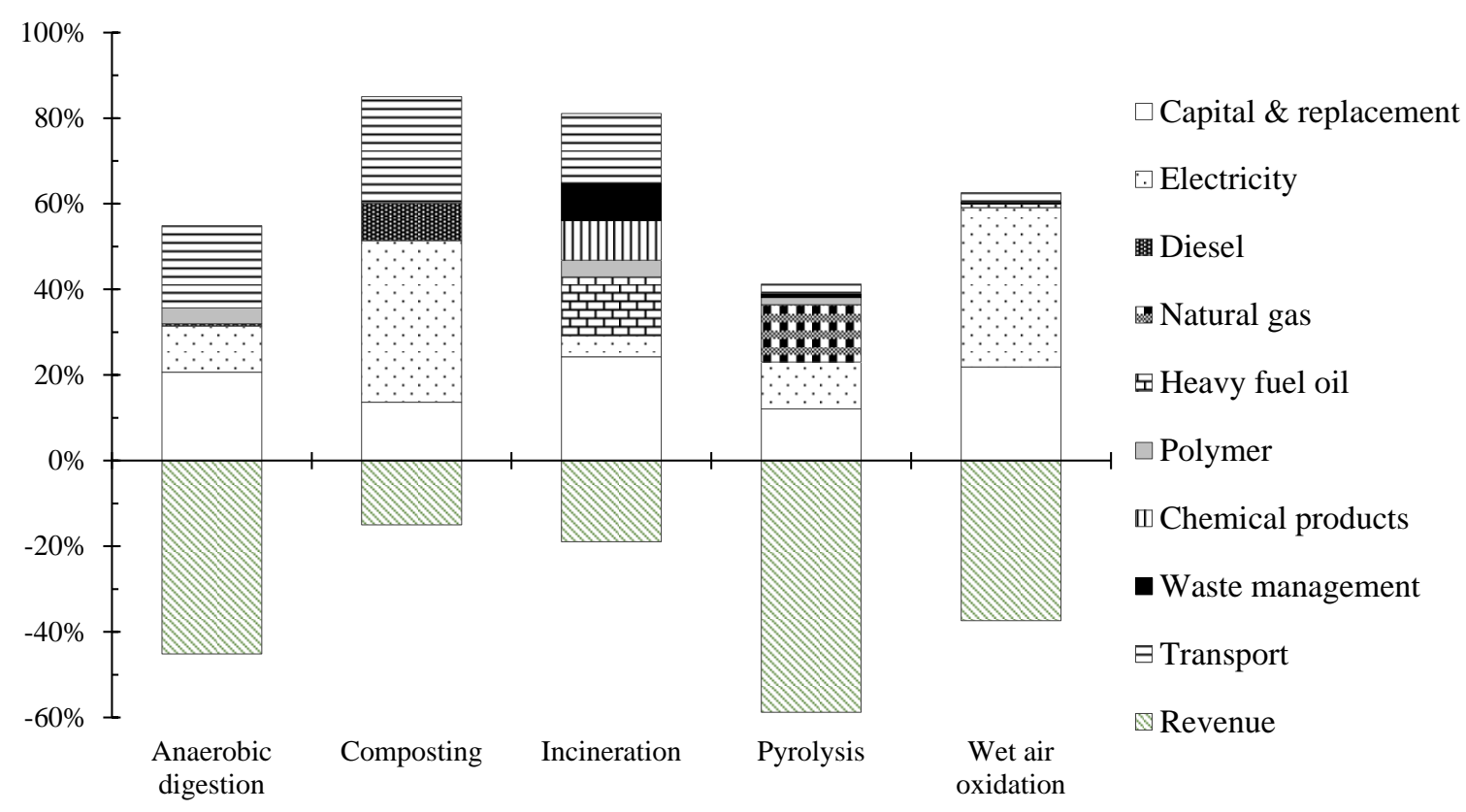

Figure 8 - Contribution of different life cycle stages to the costs of sludge treatment plants for the mean resource recovery (For the latter, see Table 4).

\subsection{Comparison of results with literature}

As mentioned in the introduction, LCC studies of advanced wastewater and sludge treatment technologies are scarce, differing in age, geographical focus, methodologies and assumptions. Therefore, the discussion below should be interpreted with that in mind.

The operating cost for GAC found in the literature range from around $£ 45$ to $£ 90 / 1,000 \mathrm{~m}^{3}$, depending on whether GAC regeneration is considered (Jeswani et al. 2015). This is between two and four times lower than the operating costs estimated in this work. The difference is due to many different assumptions, including the high cost of aluminium sulphate which was not considered in the other studies. Typical costs for nanofiltration range from $£ 90-£ 160 / 1,000 \mathrm{~m}^{3}$ (Bellona et al. 2012, Bruggen et al. 2001), which is within the range estimated in this study (£118-£153). The costs of solar-photo Fenton and ozonation reported in Miralles-Cuevas et al. (2016) are $£ 450$ and $£ 220 / 1,000 \mathrm{~m}^{3}$, respectively, both of which are two times higher than here. These differences might be due to the energy costs and the assumed plant lifespan. However, the factor of two difference between the costs of SPF and ozonation found by Miralles-Cuevas and co-workers is congruent with the findings in the present study.

The costs for sludge handling estimated here are in the range or below the values reported in the literature. For example, Healy et al. (2008) calculated the costs of anaerobic digestion and composting between $£ 110$ and $£ 195 / 1,000 \mathrm{~kg}$ DM if the fertiliser was not recovered. This compares well with $£ 99.8$ for digestion and $£ 120.2 / 1,000 \mathrm{~kg}$ for composting estimated here for the same conditions (noting that Healy et al. did not consider LCC). In China Xu et al. (2014) found costs for anaerobic digestion followed by agricultural application to be $£ 40-£ 90 / 1,000 \mathrm{~kg}$ depending on the energy recovery potential, also within the range estimated in this work. If recovery of the fertiliser is possible, Lundin et al. (2004) found that the LCC costs of anaerobic digestion could be as low as $£ 80 / 1,000 \mathrm{~kg}$ DM. This is higher than the equivalent costs in this study of $-£ 64.6 / 1,000 \mathrm{~kg}$ DM which is due to the different assumptions for product recovery as well as the dated costs in the Lundin et al. study. 
Sludge incineration costs in Europe range from $£ 300$ to $£ 400 / 1,000 \mathrm{~kg}$ DM (RPA et al. 2008) which is 2-3 times higher than the estimates here. In China, the LCC of incineration without energy recovery were found to range from $£ 75-£ 220 / 1,000 \mathrm{~kg}$ (Murray et al. 2008, Xu et al. 2014). These difference in costs are possibly due to the different assumptions and types of technology considered. If electricity and heating are recovered during incineration, Lundin et al. (2004) estimate that the LCC costs can be $£ 180 / 1,000 \mathrm{~kg}$, significantly higher than the value of $£ 102$ for no recovery calculated in this work. This could be again due to different considerations for product recovery, technology assessed and data sources.

\subsection{Sensitivity analysis}

As shown in the previous section, energy and materials contribute significantly to the overall costs of the treatment methods. Therefore, the variations in their costs are considered as part of the sensitivity analysis below. In addition, the effect on the costs of treated-sludge transportation is also evaluated as the actual distances may vary from those assumed in the study.

\subsubsection{Energy costs}

The costs of energy were varied for all the options between the minimum and maximum values given in Table 6 and the results can be seen in Figure 9a\&b. For the advanced wastewater treatment techniques, the greatest effect on the total LCC was found for ozonation, which in the best case decreased by $13 \%$ from $£ 112$ to $£ 97 / 1,000 \mathrm{~m}^{3}$ and, in the worst, increased by $12 \%$ to $£ 127 / 1,000 \mathrm{~m}^{3}$ (Figure 9a). This is due solely to the electricity cost as no other forms of energy are used in this process. Still, this alternative remains overall the cheapest wastewater treatment technique. Likewise, the costs of NF, also reliant on electricity, are affected by the variation in the electricity prices, ranging from $£ 126$ to $£ 142 / 1,000 \mathrm{~m}^{3}$, compared to the average value of $£ 134$. However, the effect on the costs of the other two alternatives is negligible $(<0.5 \%)$.

For the sludge treatment methods, the greatest effect of energy prices is on pyrolysis due to its dependence on both electricity and natural gas, with the LCC ranging from $-£ 42$ to $-£ 87 / 1,000 \mathrm{~kg}$ DM (Figure 9b). The total costs of composting vary with the energy costs by approximately $\pm 12 \%$ and of wet air ozonation by $\pm 30 \%$. However, the ranking of the options remains the same as before.

Therefore, these results suggest that the variation in energy costs does not affect the overall costs significantly and the ranking of the options is preserved across the range of the cost values (for the mean operating parameters).
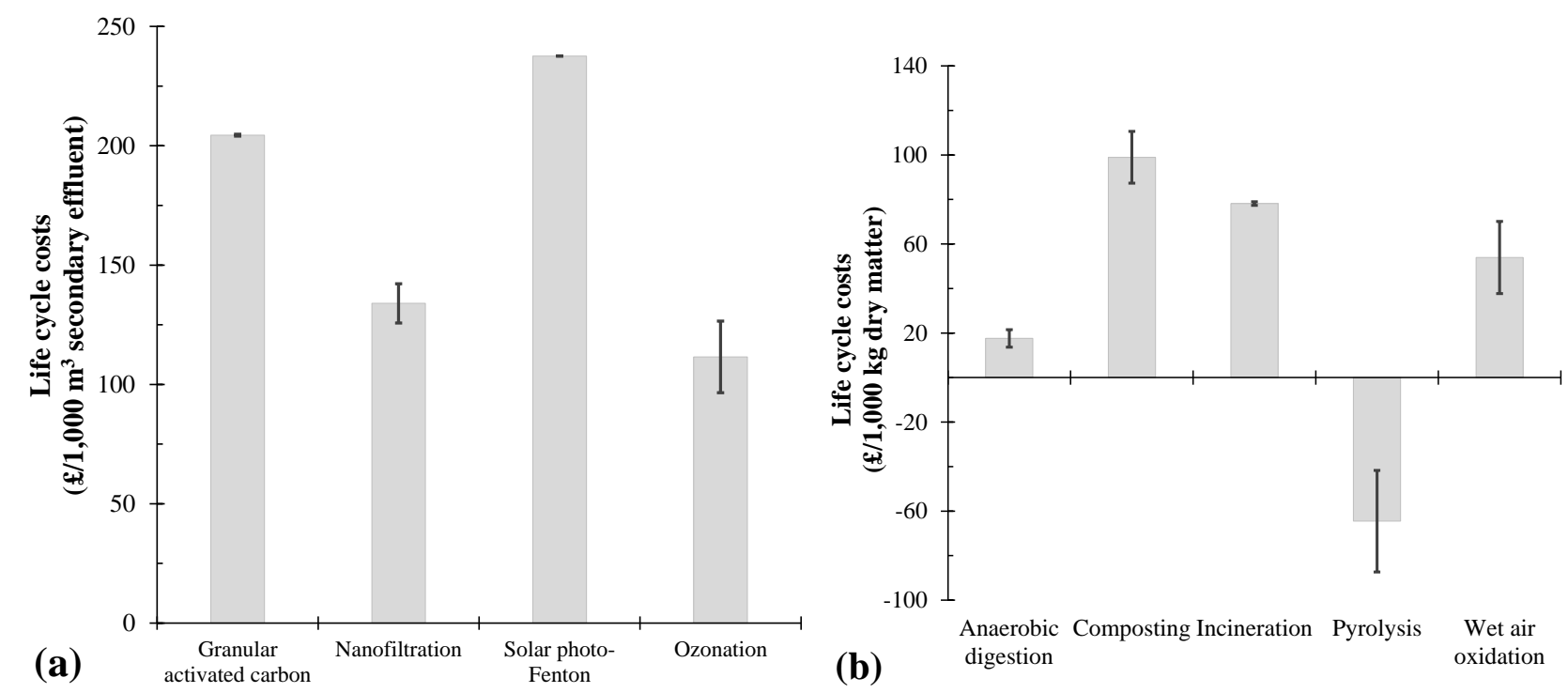

Figure 9 - Influence of energy costs on the life cycle costs of wastewater (a) and sludge (b) treatment techniques (The chart bars show the average LCC and the error bars the LCC for the minimum and maximum costs of energy given in Table 6.) 


\subsubsection{Costs of chemicals}

Like the high energy users, the alternatives relying heavily on chemicals are most influenced by their price variation. This is particularly noticeable for the GAC system which uses a significant amount of aluminium sulphate, the price of which varies widely (see Table 5). Figure 10 shows that the LCC of the GAC treatment range from $£ 120$ (imports from China) to $£ 289 / 1,000 \mathrm{~m}^{3}$ (UK production) at its mean operating requirements, representing a variation in the total costs of $30 \%$ $70 \%$. This means that in the best case, GAC is comparable to ozonation, which is on average the best option, and it becomes cheaper than NF. However, at the highest costs of chemicals, it is the most expensive option.

$\mathrm{NF}$ and SPF are also sensitive to the costs of chemicals, with their total LCC varying $\pm 31 \%$ and $\pm 17 \%$, respectively, or by around $\pm £ 41 / 1,000 \mathrm{~m}^{3}$. This is mostly due to the cost of carbon dioxide and calcium hydroxide used in the former and sodium hydroxide and sulphuric acid in the latter system. Ozonation is not affected by the costs of chemicals.

Among the sludge treatment techniques, incineration is the only option affected by the costs of chemicals (Figure 10) but only to a small degree ( 10\%), mostly due to sodium hydroxide used to balance the acid effluent from the air pollution control system.

\subsubsection{Costs of other materials: activated carbon and membranes}

Given that the costs of activated carbon contribute $25 \%$ to the total LCC of GAC, the effect of the costs of fresh and regenerated carbon on the LCC of GAC is considered here, using the cost data in Table 7. In addition, the costs of the membrane modules used in nanofiltration are considered because of their significant variation (see Table 7).

The results in Figure 11 suggest that the total LCC of GAC are not affected significantly by the variation in the costs of activated carbon, changing only by $\pm 4 \%$. A similar outcome was found for the total costs of NF, which varied by $\pm 1 \%$ with the costs of membranes.
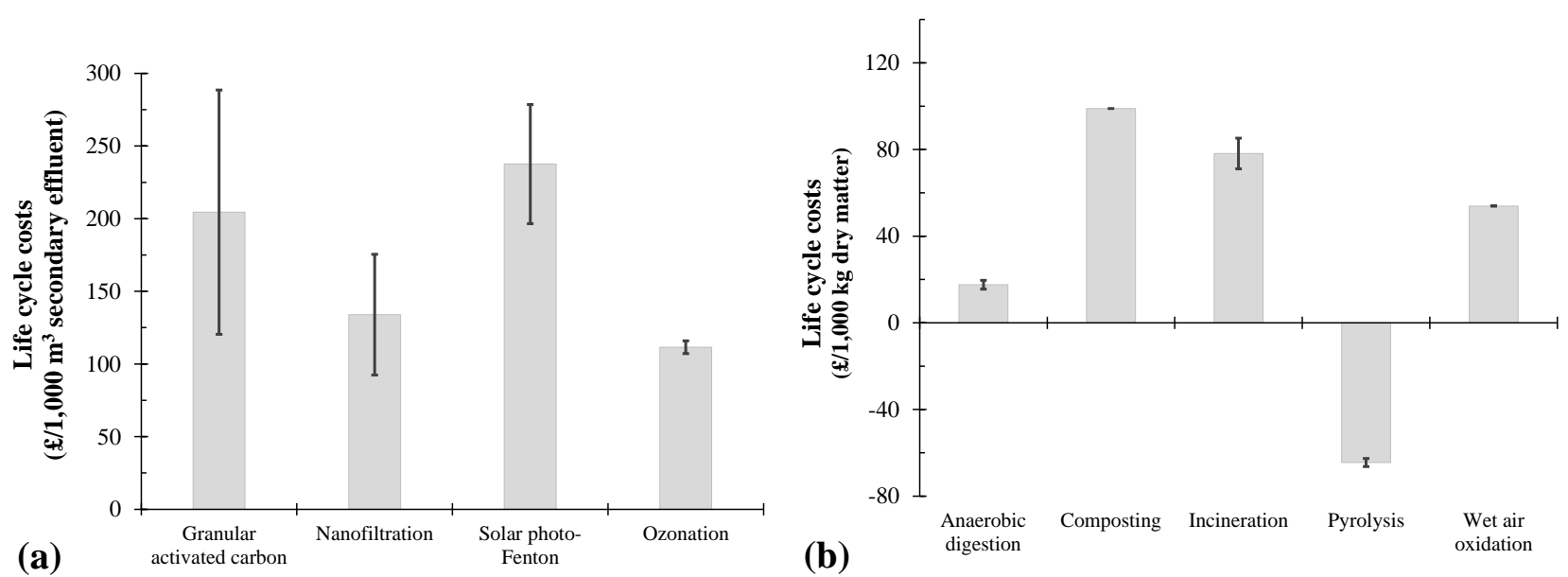

Figure 10 - Influence of the costs of chemicals on the life cycle costs of wastewater (a) and sludge (b) treatment techniques (The chart bars show the mean LCC and the error bars the LCC for the minimum and maximum costs of chemicals given in Table 5) 


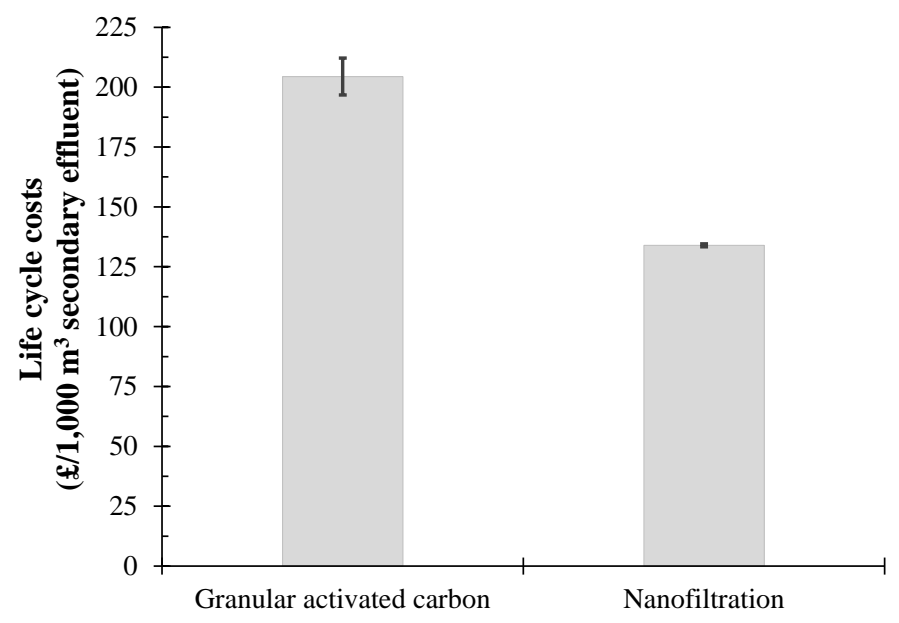

Figure 11 - Influence of the costs of activated carbon and membranes on the life cycle costs of granular activated carbon and nanofiltration (The chart bars show the mean LCC and the error bars the LCC for the minimum and maximum costs of these materials given in Table 7)

\subsubsection{Costs of digested and composted sludge transportation}

As the transportation distances of the anaerobically digested and composted sludge to the agriculture field can differ from $30 \mathrm{~km}$ assumed in this work (see Table 4), this section shows the effect on the LCC if distances are 5,15 and $50 \mathrm{~km}$ from the treatment facility (Figure 12). The results reveal that the decrease of the transportation distance from $30 \mathrm{~km}$ to $15 \mathrm{~km}$ would reduce the mean LCC costs of anaerobic digestion from $£ 18 / 1,000 \mathrm{~kg}$ to a mean profit of $£ 1 / 1,000 \mathrm{~kg}$ and for composting the mean LCC would decrease from $£ 99 / 1,000 \mathrm{~kg}$ to $£ 81 / 1,000 \mathrm{~kg}$. When the distance is decreased to $5 \mathrm{~km}$ from the facility, anaerobic digestion has a mean profit of $£ 13 / 1,000 \mathrm{~kg}$ and composting a net LCC of $£ 68 / 1,000 \mathrm{~kg}$. On the other hand, increasing the distance to $50 \mathrm{~km}$ would result in a mean LCC for anaerobic digestion of $£ 42 / 1,000 \mathrm{~kg}$ and $£ 123 / 1,000 \mathrm{~kg}$ for composting. Therefore, the effect of sludge transport distances is much higher for anaerobic digestion than for composting.

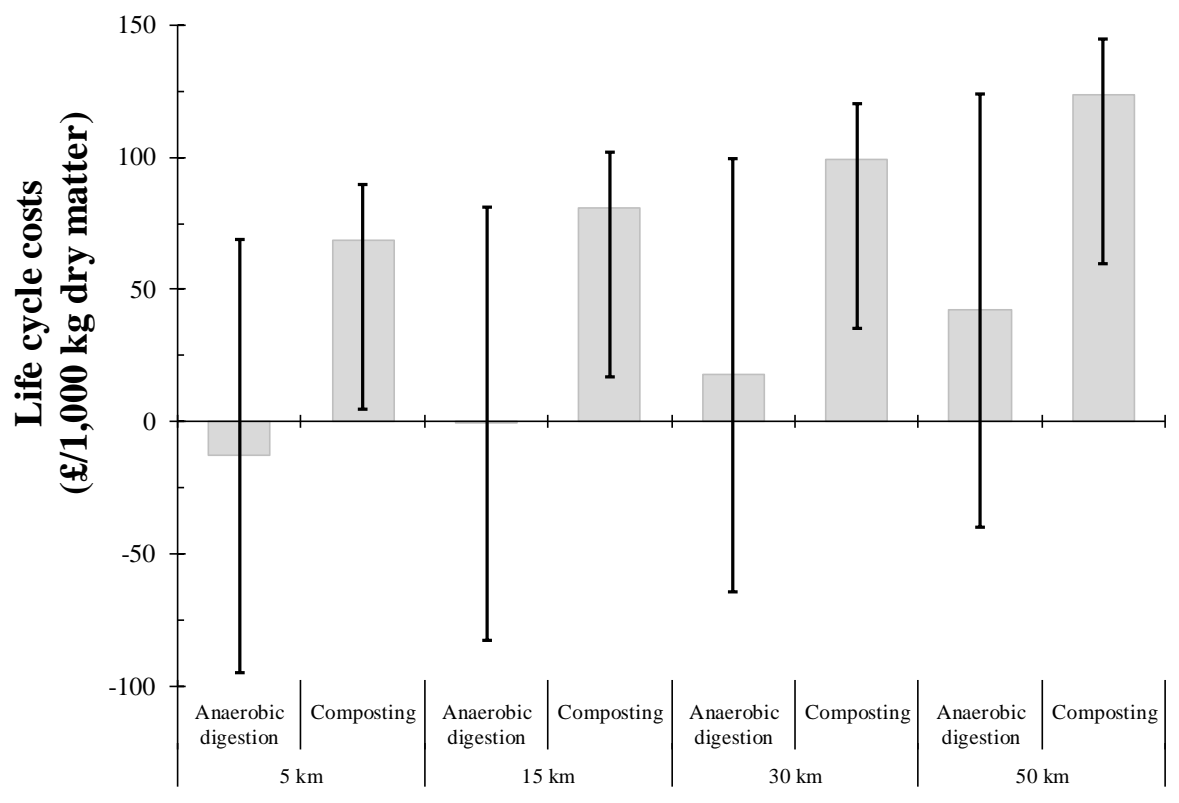

Figure 12 - Influence of transport costs of anaerobic digested and composted sludge on the total life cycle costs (The chart bars show the mean LCC and the error bars the LCC for the minimum and maximum resource recovery given in Table 4) 


\subsection{Economic feasibility of wastewater reuse and resource recovery from sludge}

Expecting water crisis in certain regions, the European Commission has identified wastewater reuse as one of the options for more sustainable water management in the European Union (European Commission 2016, Sanz \& Gawlik 2014). As a result, development of appropriate actions and regulations is being considered to enable safe reuse of wastewater in agricultural, industrial and urban environments. In the US, the Environmental Protection Agency (EPA) has already developed guidelines for implementation of different practices for direct and indirect wastewater reuse in locations affected by water scarcity (EPA 2012). Therefore, this section considers the economic feasibility of reusing the wastewater treated by the advanced treatments and compares them to the costs of potable water produced in conventional water treatment plants. In addition, the feasibility of different sludge treatment techniques is also discussed. The costs of the treatment technologies when coupled with an MBR are also discussed. MBRs are being increasingly adopted in Europe due to their efficiency in treating wastewater and also for enabling wastewater reclamation when combined with advanced treatment methods (Alturki et al. 2010, Chon et al. 2012). Thus, arguably, the total costs of wastewater reclamation should include both the MBR and advanced treatment costs.

The costs of MBR treatment at a medium to large scale $\left(\geq 19,000 \mathrm{~m}^{3} / \mathrm{d}\right)$ are estimated at $£ 150$ $£ 200 / 1,000 \mathrm{~m}^{3}$ of urban effluent (Hai et al. 2014, Singh et al. 2016). If this cost is added to the costs of the advanced wastewater treatment estimated here, the total costs range from $£ 312$ to $£ 438 / 1,000$ $\mathrm{m}^{3}$ (assuming the mean operating conditions for the advanced treatment). These costs are higher than the consumer costs of potable water in the UK, which range from $£ 160$ to $£ 240 / 1,000 \mathrm{~m}^{3}$ (South West Water 2015). However, in regions relying on desalination as a source of freshwater, the costs range between $£ 250$ and $£ 950 / 1,000 \mathrm{~m}^{3}$ (Ghaffour et al. 2013). Although these costs are not directly comparable to desalination costs in the UK, the combination of an MBR and advanced treatment methods could be considered economically feasible and could in the future be costcompetitive with desalination facilities for potable water. However, in addition to the costs, other aspects must be considered, including technical reliability of the advanced treatment methods, potential generation of hazardous by-products, regulation and social acceptance of wastewater reuse (Angelakis et al. 2018, Hong et al. 2018, Smith et al. 2018, Soller et al. 2017).

The results of this work also demonstrate that the economic viability of some sludge handling alternatives is highly dependent on the recovery potential and sales of their products. Assuming the best case scenario with all the outputs sold, anaerobic digestion and pyrolysis could potentially be more profitable than the other methods. However, the products of pyrolysis are highly variable (both quality and quantity), which hinders their use. Taking this into account, anaerobic digestion could be considered more feasible than pyrolysis because the markets for the digested sludge and electricity from biogas are well established and their use is widely practiced.

To contextualise the above results, Figure 13 shows the daily costs of least costly treatment technologies integrated within a conventional WWTP with an MBR and sludge thickener, treating $64,000 \mathrm{~m}^{3} /$ day. As can be seen, the costs of conventional treatment is estimated at around $£ 12,700 /$ day. Adding ozonation with pyrolysis, anaerobic digestion or incineration, brings up the total costs to $£ 19,400-20,400 /$ day, respectively, assuming their mean operating parameters and resource recovery. At the most favourable conditions, i.e. ozonation at its lowest operating requirements and sludge techniques with the highest revenues, the total cost of around $£ 15,000 /$ day is possible. NF can reach costs similar to ozonation (both with the respective sludge treatments) only at its best operating conditions. GAC would only be able to achieve costs similar to the ozonation (plus sludge treatments) when the former is operating at its best and the latter at the worst conditions. Otherwise, the mean costs of coupling NF and sludge treatment with the conventional wastewater treatment would range from $£ 20,800-21,900 /$ day. The equivalent mean costs of adding 
GAC and sludge treatments would be $£ 25,300-26,400 /$ day. Thus, the advanced wastewater and sludge treatment would increase the costs of conventional wastewater treatment by 1.5-2.1 times.

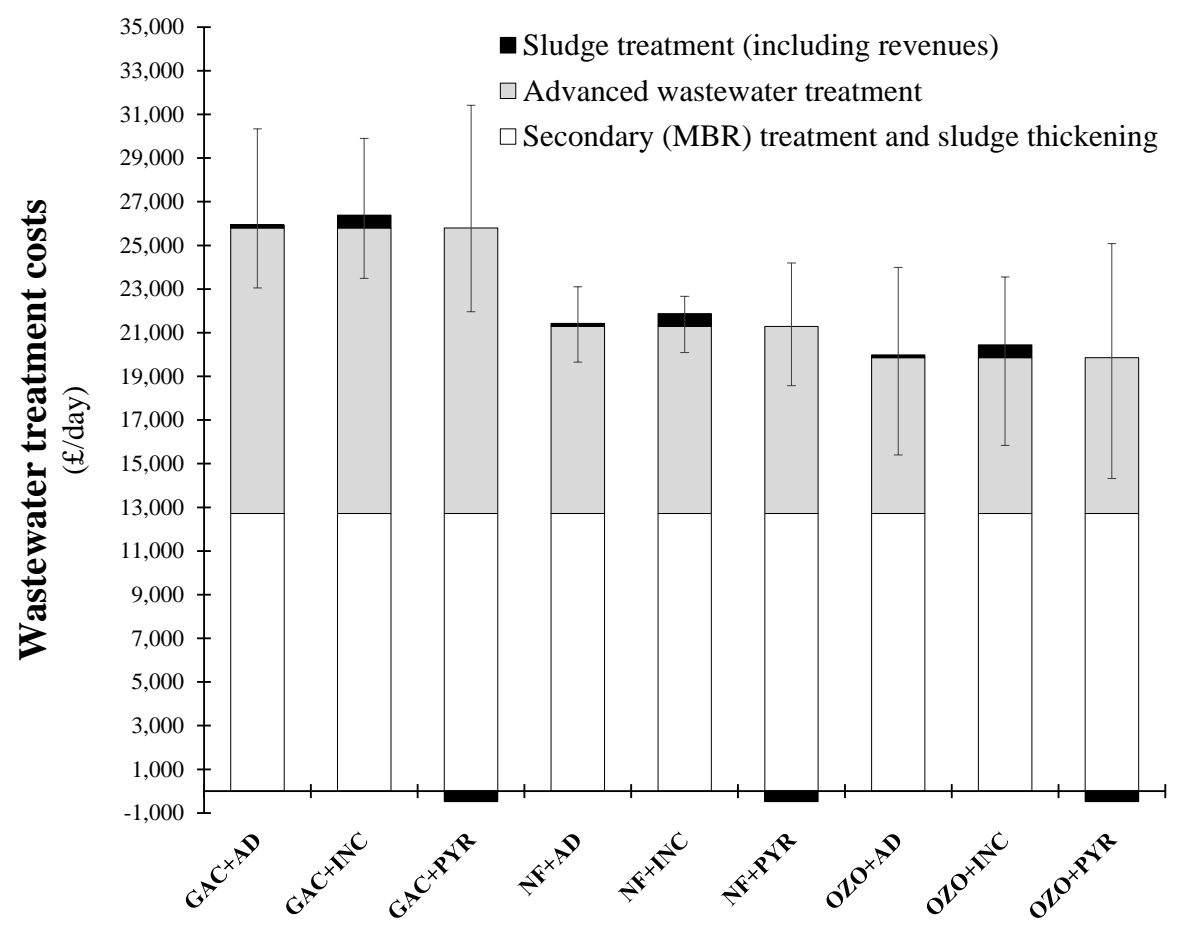

Figure 13 - Comparison of the total costs for the treatment of $64,000 \mathrm{~m}^{3} / \mathrm{d}$ of urban wastewaters combining conventional with advanced wastewater and sludge treatment. (Costs for solar photo-Fenton, composting and wet air oxidation are excluded due to the high costs compared to the other alternatives. Membrane bioreactor (MBR) consumes $1,650 \mathrm{kWh} / \mathrm{d}$ of electricity (Singh et al. 2016) and belt thickening $50 \mathrm{kWh} / \mathrm{d}$ (Suh \& Rousseaux 2002). Error bars represent the minimum and maximum values of the operating parameters and resource recovery (see Table 3 and Table 4). GAC: granular activated carbon; NF: nanofiltration; OZO: ozonation; AD: anaerobic digestion; INC: incineration; PYR: pyrolysis.)

\section{Conclusions}

This study considered life cycle costs of advanced wastewater treatment methods aimed at recovery of potable water, alongside costs of different techniques for recovery of resources from sludge. Among the wastewater treatment options considered, ozonation is the least expensive, averaging $£ 112$ per $1,000 \mathrm{~m}^{3}$ of treated secondary effluent. Solar photo-Fenton has the highest costs $\left(£ 238 / 1,000 \mathrm{~m}^{3}\right)$, followed by granular activated carbon $\left(£ 205 / 1,000 \mathrm{~m}^{3}\right)$. However, the costs vary significantly with the operating parameters. For example, in the best case the costs of granular activated carbon are comparable with the top range of the ozonation costs. Similarly, for the most favourable conditions solar photo-Fenton is competitive with nanofiltration. Nevertheless, ozonation is by far the cheapest option assuming its best performance, costing only $£ 52 / 1,000 \mathrm{~m}^{3}$. These costs are currently lower than desalination costs and could also be competitive with conventional potable water in the future. These results can be used to inform development of future guidelines on the economic feasibility of wastewater reuse. However, consumer acceptance of reused water may be a significant barrier that should be explored further.

For the resource recovery from sludge, pyrolysis is the best option with an average net profit of $£ 65 / 1,000 \mathrm{~kg}$ dry mater. Anaerobic digestion is the next least costly alternative with costs of $£ 17.6$, followed by wet air oxidation at $£ 54$. With the mean cost estimated at $£ 98.9 / 1,000 \mathrm{~kg}$, composting is the most expensive method for sludge treatment. However, there is a significant variation in the costs, depending on the assumptions for the sales of the products. For instance, the profits from pyrolysis would increase by a factor of four if all the outputs are sold, but if there is no recovery of products, its overall costs amount to $£ 162 / 1,000 \mathrm{~kg}$. Assuming the most favourable conditions, 
incineration can operate at $£ 54.3$ but in the worst-case scenario, its costs exceed the maximum costs of anaerobic digestion ( $£ 102$ vs $£ 99.8 / 1,000 \mathrm{~kg}$ ). Therefore, the economic viability of the sludge treatment options is highly dependent on the recovery rates and the revenue from the recovered resources and should be assessed carefully on a case-by-case basis for different sites and regions.

\section{Acknowledgements}

The authors would like to acknowledge CNPq (Brazilian National Council for Scientific and Technological Development) for the financial support (grant number 238021/2012-2).

\section{Appendix}

Table A1 - Further information on granular activated carbon and ozonation

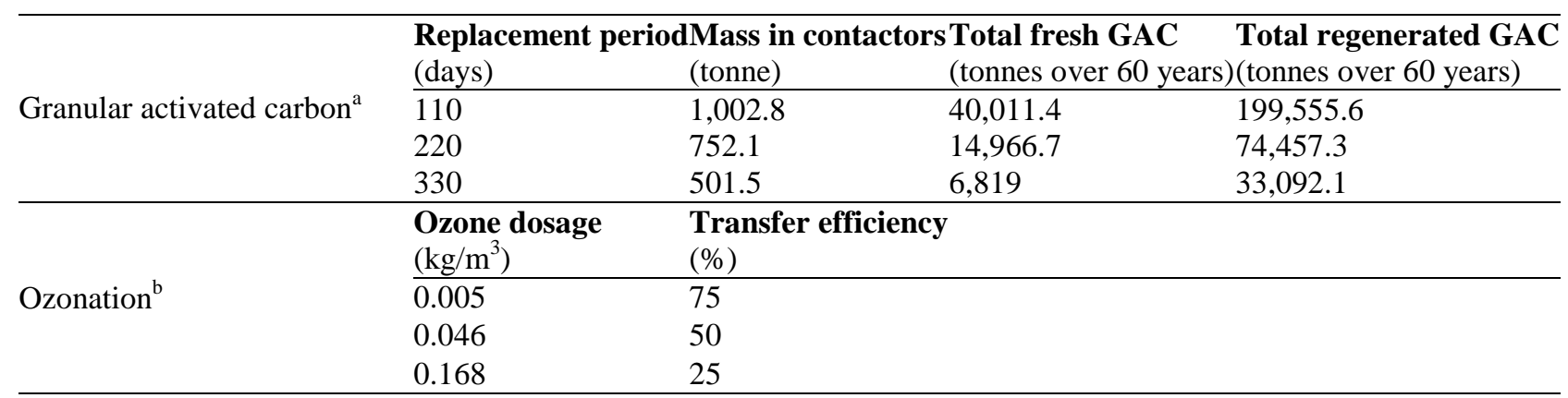

${ }^{\mathrm{a}}$ Calculated for the empty bed contact times (EBCT) of 20 to 40 minutes.

${ }^{\mathrm{b}}$ Data from Wang et al. (2005).

\section{References}

Agroshop. 2016. http://agroshop.onlinewebshop.net/index.php?lang=en

Alliance UK. 2016. https://www.allianceuk.com/

Alturki AA, Tadkaew N, McDonald J a., Khan SJ, Price WE, Nghiem LD. 2010. Combining MBR and NF/RO membrane filtration for the removal of trace organics in indirect potable water reuse applications. J. Memb. Sci. 365(1-2):206-15

Angelakis AN, Asano T, Bahri A, Jimenez BE, Tchobanoglous G. 2018. Water Reuse : From Ancient to Modern Times and the Future. Front. Envirommental Sci. 6(May):

Anqiu Hengan Gas Manufacture Factory. 2016. http://www.hengangas.com

Archer E, Petrie B, Kasprzyk-Hordern B, Wolfaardt GM. 2017. The fate of pharmaceuticals and personal care products (PPCPs), endocrine disrupting contaminants (EDCs), metabolites and illicit drugs in a WWTW and environmental waters. Chemosphere. 174:437-46

Bailey ES, Casanova LM, Simmons OD, Sobsey MD. 2018. Tertiary treatment and dual disinfection to improve microbial quality of reclaimed water for potable and non-potable reuse: A case study of facilities in North Carolina. Sci. Total Environ. 630:379-88

Bayer P, Heuer E, Karl U, Finkel M. 2005. Economical and ecological comparison of granular activated carbon (GAC) adsorber refill strategies. Water Res. 39(9):1719-28

Bellona C, Heil D, Yu C, Fu P, Drewes JE. 2012. The pros and cons of using nanofiltration in lieu of reverse osmosis for indirect potable reuse applications. Sep. Purif. Technol. 85:69-76

Binz C, Harris-Lovett S, Kiparsky M, Sedlak DL, Truffer B. 2016. The thorny road to technology legitimation - Institutional work for potable water reuse in California. Technol. Forecast. Soc. Change. 103:249-63

Bonton A, Bouchard C, Barbeau B, Jedrzejak S. 2012. Comparative life cycle assessment of water treatment plants. Desalination. 284:42-54

British Plastics Federation. 2016. http://www.bpf.co.uk/

Bruggen B Van Der, Everaert K, Wilms D, Vandecasteele C. 2001. Application of nanofiltration for removal of pesticides, nitrate and hardness from ground water: Rejection properties and economic evaluation. J. Memb. Sci. 193:239-48 
Chengde Hongya Activated Carbon. 2016. http://www.sjn.cn/company/1401012842.shtml

Chon K, KyongShon H, Cho J. 2012. Membrane bioreactor and nanofiltration hybrid system for reclamation of municipal wastewater: Removal of nutrients, organic matter and micropollutants. Bioresour. Technol. 122:181-88

Cyna B, Chagneaub G, Bablon G, Tanghe N. 2002. Two years of nanofiltration at the M \& y-surOise plant , France. . 147:69-75

DEFRA. 2012. Waste water treatment in the United Kingdom. London

Department of Energy and Climate Change. 2015. Quarterly energy prices

Easychemtrade. 2016. http://www.easychemtrade.co.uk/

eawag. 2014. Faecal Sludge Management - Systems Approach for Implementation and Operation. Dübendorf, $\mathrm{CH}$ : IWA publishing

Elazhar F, Tahaikt M, Achatei A, Elmidaoui F, Taky M, et al. 2009. Economical evaluation of the fluoride removal by nanofiltration. Desalination. 249(1):154-57

Elser J, Bennett E. 2011. Phosphorus cycle: A broken biogeochemical cycle. Nature. 478(7367):2931

EPA. 2012. Guidelines for Water Reuse

European Commission. 2016. Guidelines on Integrating Water Reuse into Water Planning and Management in the context of the WFD. Brussels, Belgium

Fonts I, Gea G, Azuara M, Ábrego J, Arauzo J. 2012. Sewage sludge pyrolysis for liquid production: A review. Renew. Sustain. Energy Rev. 16(5):2781-2805

Fytili D, Zabaniotou A. 2008. Utilization of sewage sludge in EU application of old and new methods - A review. Renew. Sustain. Energy Rev. 12(1):116-40

Ganzhou Green Top Biological Technology. 2016. http://greentopfertilizer.lookchem.com

Garcia X, Pargament D. 2015. Reusing wastewater to cope with water scarcity: Economic, social and environmental considerations for decision-making. Resour. Conserv. Recycl. 101:154-66

Gas UK. 2016. https://www.gas-uk.co.uk/

Ghaffour N, Missimer TM, Amy GL. 2013. Technical review and evaluation of the economics of water desalination: Current and future challenges for better water supply sustainability. Desalination. 309(2013):197-207

González O, Bayarri B, Acena J, Perez S, Barcelo D. 2015. Treatment Technologies for Wastewater Reuse: Fate of Contaminants of Emerging Concern. In Advanced Treatment Technologies for Urban Wastewater Reuse, eds. D Fatta-Kassinos, DD Dionysiou, K Kummerer, pp. 5-37. Springer

Guangdong Qiangda New Materials Technology. 2016. http://qde20150629.en.made-in-china.com/

Guangxi Qinzhou Capital Chemical. 2016. http://www.globalsources.com/si/AS/GuangxiQinzhou/6008834688502/Homepage.htm

Hai FI, Yamamoto K. 2011. Membrane Biological Reactors. In Treatise on Water Science, pp. 571613. Elsevier

Hai FI, Yamamoto K, Lee C-H. 2014. Cost benefit and environmental Life Cycle Assessment. In Membrane Biological Reactors: Theory, Modeling, Desing, Management and Applications to Wastewater Reuse, pp. 223-61. Glasgow: IWA publishing

Harris-Lovett SR, Binz C, Sedlak DL, Kiparsky M, Truffer B. 2015. Beyond User Acceptance: A Legitimacy Framework for Potable Water Reuse in California. Environ. Sci. Technol. 49(13):7552-61

Healy MG, Clarke R, Peyton D, Cummins E, Moynihan EL, Martins A. 2008. Resource recovery from sewage sludge. In Sewage Treatment Plants - Economic of Inovative Technologies for Energy Efficiency, eds. K Stamatelatou, KP Tsagarakis, p. 376. IWA publishing

Hebei Xiongye Machine Trade. 2016. https://www.importgenius.com/suppliers/hebei-xiongyemachine-trade-co-ltd

Hii K, Baroutian S, Parthasarathy R, Gapes DJ, Eshtiaghi N. 2014. A review of wet air oxidation and Thermal Hydrolysis technologies in sludge treatment. Bioresour. Technol. 155:289-99

Hong J, Hong J, Otaki M, Jolliet O. 2009. Environmental and economic life cycle assessment for 
sewage sludge treatment processes in Japan. Waste Manag. 29(2):696-703

Hong PY, Julian TR, Pype ML, Jiang SC, Nelson KL, et al. 2018. Reusing treated wastewater: Consideration of the safety aspects associated with antibiotic-resistant bacteria and antibiotic resistance genes. Water. 10(3):

Hospido A, Moreira MT, Martin M, Rigola M, Feijoo G. 2005. Environmental evaluation of different treatment processes for sludge from urban wastewater treatments: Anaerobic digestion versus thermal processes. Int. J. Life Cycle Assess. 10(5):336-45

Houdková L, Boráň J, Ucekaj V, Elsäßer T, Stehlík P. 2008. Thermal processing of sewage sludge II. Appl. Therm. Eng. 28(16):2083-88

Houillon G, Jolliet O. 2005. Life cycle assessment of processes for the treatment of wastewater urban sludge: Energy and global warming analysis. J. Clean. Prod. 13(3):287-99

Hung Y-T, Wang LK, Nazih KS. 2013. Handbook of Environment and Waste Management: Volume 2: Land and Groundwater Pollution Control

Iranpour R, Cox HHJ, Kearney RJ, Clark JH, Pincince AB, Daigger GT. 2004. Regulations for biosolids land application in US and European Union. J. Residuals Sci. Technol. 1(4):209-22

Jeswani HK, Gujba H, Brown NW, Roberts EPL, Azapagic A. 2015. Removal of organic compounds from water: life cycle environmental impacts and economic costs of the Arvia process compared to granulated activated carbon. J. Clean. Prod. 89:203-13

Jinan Yuxing Chemical. 2016. http://www.lxyx.chemchina.com/jnyxen/

Kelessidis A, Stasinakis AS. 2012. Comparative study of the methods used for treatment and final disposal of sewage sludge in European countries. Waste Manag. 32(6):1186-95

Khan S. 2013. Drinking water through recycling: The benefits and costs of supplying direct to the distribution system. Melbourne Victoria, Australia

Klamerth N. 2011. Application of a solar photo-Fenton for the treatment of contaminants in municipal wastewater effluents. University of Almeria

Laera G, Cassano D, Lopez A, Pinto A, Pollice A, et al. 2012. Removal of Organics and Degradation Products from Industrial Wastewater by a Membrane Bioreactor Integrated with Ozone or UV/ H 2 O 2 Treatment. Environ. Sci. Technol. 46:1010-18

Lahnsteiner J, van Rensburg P, Esterhuizen J. 2018. Direct potable reuse - a feasible water management option. J. Water Reuse Desalin. 8(1):14-28

Larsen TA, Hoffmann S, Luthi C, Truffer B, Maurer M. 2016. Emerging solutions to the water challenges of an urbanizing world. Science (80-. )., , pp. 928-33

Libralato G, Volpi Ghirardini A, Avezzù F. 2012. To centralise or to decentralise: An overview of the most recent trends in wastewater treatment management. J. Environ. Manage. 94(1):61-68

Lofrano G. 2012. Emerging Compounds Removal from Wastewater, Natural and Solar Based Treatments. Salermo: Springer

Lu Q, He ZL, Stoffella PJ. 2012. Land application of biosolids in the USA: A review. Appl. Environ. Soil Sci. 2012:

Lundin M, Olofsson M, Pettersson GJ, Zetterlund H. 2004. Environmental and economic assessment of sewage sludge handling options. Resour. Conserv. Recycl. 41(4):255-78

Lyons G. 2014. Pharmaceuticals in the environment: A growing threat to our tap water and wildlife. London

McDonald RI, Weber K, Padowski J, Flörke M, Schneider C, et al. 2014. Water on an urban planet: Urbanization and the reach of urban water infrastructure. Glob. Environ. Chang. 27(1):96-105

Miralles-Cuevas S, Oller I, Agüera A, Pérez JAS, Sánchez-Moreno R, Malato S. 2016. Is the combination of nanofiltration membranes and AOPs for removing microcontaminants cost effective in real municipal wastewater effluents? Environ. Sci. Water Res. Technol. 2(3):51120

Mistral Industrial Chemicals. 2016. https://mistralni.co.uk/

Mo W, Zhang Q. 2013. Energy-nutrients-water nexus: Integrated resource recovery in municipal wastewater treatment plants. J. Environ. Manage. 127:255-67

Muñoz I. 2006. Life cycle assessment as a tool for green chemistry: application to different 
advanced oxidation processes for wastewater treatment. Universitat Autonoma de Barcelona

Muñoz I, Peral J, Antonio Ayllón J, Malato S, José Martin M, et al. 2007. Life-Cycle Assessment of a Coupled Advanced Oxidation-Biological Process for Wastewater Treatment: Comparison with Granular Activated Carbon Adsorption. Environ. Eng. Sci. 24(5):638-51

Murray A, Horvath A, Nelson KL. 2008. Hybrid life-cycle environmental and cost inventory of sewage sludge treatment and end-use scenarios: A case study from China. Environ. Sci. Technol. 42(9):3163-69

OECD. 2012. The OECD Environmental Outlook to 2050 - The Consequences of Inaction. Paris, France: OECD Publishing

Pasqualino JC, Meneses M, Abella M, Castells F. 2009. LCA as a decision support tool for the environmental improvement of the operation of a municipal wastewater treatment plant. Environ. Sci. Technol. 43(9):3300-3307

Pereira AMPT, Silva LJG, Lino CM, Meisel LM, Pena A. 2017. A critical evaluation of different parameters for estimating pharmaceutical exposure seeking an improved environmental risk assessment. Sci. Total Environ. 603-604:226-36

poundsterlinglive. 2018. . https://www.poundsterlinglive.com/bank-of-england-

Qingdao Huatuo Chemical. 2016. http://www.hotchem.cn/

ReAgent. 2016. http://www.reagent.co.uk/

Ribeiro AR, Nunes OC, Pereira MFR, Silva AMT. 2015. An overview on the advanced oxidation processes applied for the treatment of water pollutants defined in the recently launched Directive 2013/39/EU. Environ. Int. 75:33-51

RPA, WRC, milieu. 2008. Environmental, economic and social impacts of the use of sewage sludge on land Final Report Part II: Report on Options and Impacts

Sablayrolles C, Gabrielle B, Montrejaud-Vignoles M. 2010. Life Cycle Assessment of Biosolids Land Application and Evaluation of the Factors Impacting Human Toxicity through Plant Uptake. J. Ind. Ecol. 14(2):231-41

Sanz LA, Gawlik BM. 2014. Water Reuse in Europe - Water Reuse in Europe Relevant guidelines, needs for and barriers to innovation. Luxenburg

ServApure. 2016. http://www.servapure.com/

Shandong Sanfeng group. 2016. http://en.sanfengchem.com/

Shijiazhuang City Horizon Chemical. 2016. http://www.horizonadmixtures.com/

Shijiazhuang Xinlongwei Chemical. 2016. http://www.sjzxlwhg.com/

Simha P, Ganesapillai M. 2017. Ecological Sanitation and nutrient recovery from human urine: How far have we come? A review. Sustain. Environ. Res. 27(3):107-16

Singh P, Kansal A, Carliell-Marquet C. 2016. Energy and carbon footprints of sewage treatment methods. J. Environ. Manage. 165:22-30

Smith HM, Brouwer S, Jeffrey P, Frijns J. 2018. Public responses to water reuse - Understanding the evidence. J. Environ. Manage. 207:43-50

Soller JA, Eftim SE, Warren I, Nappier SP. 2017. Evaluation of microbiological risks associated with direct potable reuse. Microb. Risk Anal. 5:3-14

South West Water. 2015. Forecast average household bills

Spielmann M, Bauer C, Dones R, Tuchschmid M. 2007. Transport Services. Dübendorf

Suh YJ, Rousseaux P. 2002. An LCA of alternative wastewater sludge treatment scenarios. Resour. Conserv. Recycl. 35(3):191-200

Swarr TE, Hunkeler D, Klöpffer W, Pesonen HL, Ciroth A, et al. 2011. Environmental life-cycle costing: A code of practice. Int. J. Life Cycle Assess. 16(5):389-91

Tran NH, Reinhard M, Gin KYH. 2018. Occurrence and fate of emerging contaminants in municipal wastewater treatment plants from different geographical regions-a review. Water Res. 133(December):182-207

Treewood. 2016. https://heyfarmshops.co.uk/01453963/Treewood_Charcoal

Trovó AG, Silva TFS, Gomes O, Machado AEH, Neto WB, et al. 2013. Degradation of caffeine by photo-Fenton process: Optimization of treatment conditions using experimental design. 
Chemosphere. 90(2):170-75

Tyagi VK, Lo SL. 2013. Sludge: A waste or renewable source for energy and resources recovery? Renew. Sustain. Energy Rev. 25(71):708-28

Umbach F. 2010. Global energy security and the implications for the EU. Energy Policy. 38(3):1229-40

United Nations. 2018. Nature-based solutions for water. Paris, France

Van Der Hoek JP, De Fooij H, Struker A. 2016. Wastewater as a resource: Strategies to recover resources from Amsterdam's wastewater. Resour. Conserv. Recycl. 113:53-64

Voulvoulis N. 2018. Water Reuse from a Circular Economy Perspective and Potential Risks from an Unregulated Approach. Curr. Opin. Environ. Sci. Heal. 2:32-45

Wang J, Wang S. 2016. Removal of pharmaceuticals and personal care products (PPCPs) from wastewater: A review. J. Environ. Manage. 182:620-40

Wang L, Hung Y-T, Shammas N. 2005. Physicochemical Treatment Processes, Vol. 3. New Jersey: Humana Press Inc.

Wang L, Shammas NK, Evanylo G. 2008. Biosolids Engineering and Management. Totowa, New Jersey: Humana Press Inc.

Which? 2015. Turning up the heat: Getting a fair deal for Distric Heating users. London, UK

World Freight Rates. 2016. www.worldfreight.rates.com

WRAP. 2013. Comparing the costs of alternative waste treatment options. Banbury, UK

Wuhan Guotai Hongfa Commodity. 2016. http://www.whgthf.com/

$\mathrm{Xu} \mathrm{C}$, Chen W, Hong J. 2014. Life-cycle environmental and economic assessment of sewage sludge treatment in China. J. Clean. Prod. 67:79-87

Zhang Y, Shen Y. 2017. Wastewater irrigation: past, present, and future. Wiley Interdiscip. Rev. Water. e1234

Zhengzhou Qiangjin. 2016. http://yustrongerhn.ecol.xyz/

Zhuzhou Rongda Chemical. 2016. http://www.rongdachemco.com/

Zouping Runzi Chemical Industry. 2016. http://www.runzichem.cn/ 